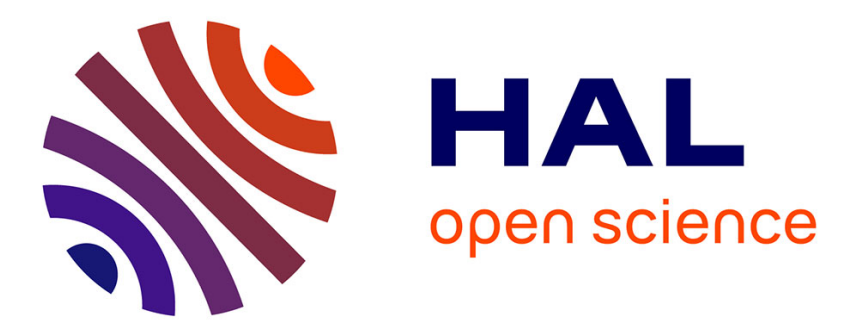

\title{
Magmatic history of central Myanmar and implications for the evolution of the Burma Terrane
}

\author{
Alexis Licht, Zaw Win, Jan Westerweel, Nathan Cogné, Chris Morley, \\ Sarawute Chantraprasert, Fernando Poblete, Tamas Ugrai, Bruce Nelson, Day \\ Wa Aung, et al.
}

\section{To cite this version:}

Alexis Licht, Zaw Win, Jan Westerweel, Nathan Cogné, Chris Morley, et al.. Magmatic history of central Myanmar and implications for the evolution of the Burma Terrane. Gondwana Research, 2020, 87, pp.303-319. 10.1016/j.gr.2020.06.016 . insu-02915966

\section{HAL Id: insu-02915966 https://hal-insu.archives-ouvertes.fr/insu-02915966}

Submitted on 17 Aug 2020

HAL is a multi-disciplinary open access archive for the deposit and dissemination of scientific research documents, whether they are published or not. The documents may come from teaching and research institutions in France or abroad, or from public or private research centers.
L'archive ouverte pluridisciplinaire HAL, est destinée au dépôt et à la diffusion de documents scientifiques de niveau recherche, publiés ou non, émanant des établissements d'enseignement et de recherche français ou étrangers, des laboratoires publics ou privés. 


\title{
Journal Pre-proof
}

Magmatic history of central Myanmar and implications for the evolution of the Burma Terrane

Alexis Licht, Zaw Win, Jan Westerweel, Nathan Cogné, Chris Morley, Sarawute Chantraprasert, Fernando Poblete, Tamas Ugrai, Bruce Nelson, Day Wa Aung, Guillaume Dupont-Nivet

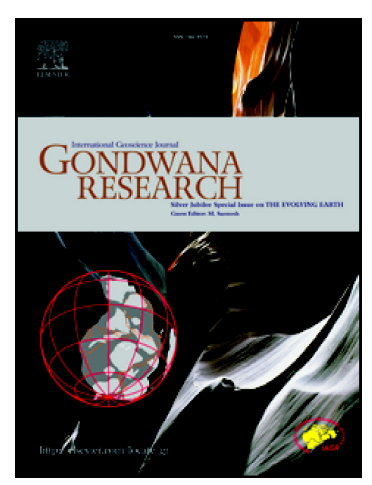

PII:

S1342-937X(20)30208-2

DOI: https://doi.org/10.1016/j.gr.2020.06.016

Reference:

GR 2383

To appear in:

\author{
Gondwana Research
}

Received date:

24 April 2020

Revised date:

15 June 2020

Accepted date:

16 June 2020

Please cite this article as: A. Licht, Z. Win, J. Westerweel, et al., Magmatic history of central Myanmar and implications for the evolution of the Burma Terrane, Gondwana Research (2020), https://doi.org/10.1016/j.gr.2020.06.016

This is a PDF file of an article that has undergone enhancements after acceptance, such as the addition of a cover page and metadata, and formatting for readability, but it is not yet the definitive version of record. This version will undergo additional copyediting, typesetting and review before it is published in its final form, but we are providing this version to give early visibility of the article. Please note that, during the production process, errors may be discovered which could affect the content, and all legal disclaimers that apply to the journal pertain.

(C) 2020 Published by Elsevier. 


\title{
Magmatic history of central Myanmar and implications for the evolution of the
}

\section{Burma Terrane}

\author{
Alexis Licht (1)*, Zaw Win (2), Jan Westerweel (3), Nathan Cogné (3), Chris Morley (4), Sarawute
} Chantraprasert (4), Fernando Poblete (3,5), Tamas Ugrai (1), Bruce Nelson (1), Day Wa Aung (6) and Guillaume Dupont-Nivet $(3,7,8)$

(1) Department of Earth and Space Sciences, University of Washington. Seattle WA 98195, USA.

(2) Geology Department, Shwe Bo University, Sagaing Region, Myan ıaı .

(3) Géosciences Rennes, UMR CNRS 6118, Univ. Rennes, 3504? ^'enn «s Cedex, France.

(4) PTTEP, Bangkok, Thailand

(5) Departamento de Geología, Universidad de Chil :, '‘a ntiago, Chile.

(6) Geology Department, University of Yangon Py y Ra, Yangon, Myanmar.

(7) Potsdam University, Institute of Earth anu Environmental Science, 14476 Potsdam, Germany.

(8) Key Laboratory of Orogenic Belts ard $\mathrm{Cl}_{1}$ ral Evolution, Ministry of Education, Beijing, China.

* Corresponding author (e-mail: lichte' 'Iw.edu; address: Department of Earth and Space Sciences, University of Washington, Jnhin A Hall Rm-070, Box 351310, Seattle, WA 98195-1310 USA)

Abbreviated title: Magmatic history of central Myanmar

\begin{abstract}
:
The Burma Terrane is a microplate at the eastern edge of the Himalayan-Tibetan orogen, the origin of which remains poorly understood. Its basement comprises metamorphic and igneous rocks forming the WunthoPopa Arc (WPA) and has been correlated with Tibetan, Gondwana or Transtethyan rocks. Yet, little is known about the magmatic history of the WPA. We report elemental and Sr-Nd isotopic compositions of magmatic rocks, crystallization (zircon and apatite $\mathrm{U}-\mathrm{Pb}$ ) and exhumation (apatite fission-track) ages from rocks and river sands, and structural measurements from the Wuntho Ranges, central Myanmar, where the
\end{abstract}


WPA is best exposed. We show that the WPA in the Wuntho Ranges is characterized by two magmatic events at 108-90 Ma and 46-32 Ma. Magmatism is subduction-related for both events, characterized by depleted $\mathrm{Nd}$ and $\mathrm{Sr}$ isotopic compositions, with more enriched values with time. Apatite fission-track data suggest arc exhumation during the 39-22 Ma time interval, partly overlapping with the last magmatic event. Structural data indicate NW-SE-striking tilting, folding, and thrusting that we associate with at least two phases of deformation, in the Cretaceous and the late Paleogene. Correlating the WPA with Tibetan, Gondwana or Transtethyan rocks based on its magmatic history remains ambiguous; however, models arguing for a Transtethyan origin for the WPA are most compatible with our results combined with available Burmese geological data.

keywords: Myanmar, Magmatism, Tibet, India-Asia Collision, Tra ${ }^{t h y}$ an arc

\section{Introduction}

The Tibetan-Himalayan orogen is a puzzling assemblag $v^{*}$ individual terranes that have been shortened,

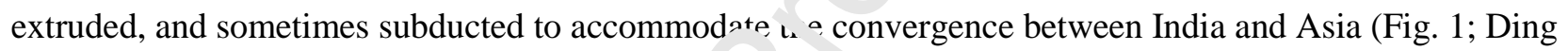
et al., 2001). Documenting the affinity and history if these terranes is particularly critical to reconstruct how the convergence has been accommodated alnng . he Asian margin, a topic that is still controversial (e.g., Shen

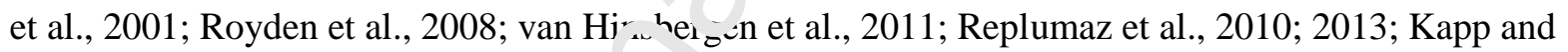
DeCelles, 2019).

Located at the southern edge of $:$ custern Himalayan Syntaxis, Myanmar hosts less deformed remnants of these terranes that have only 1 - rently been the focus of geological investigations. In particular, recent paleomagnetic results showing late Cretaceous to Eocene equatorial paleolatitudes for parts of Myanmar imply a complete revision of the number, location, and evolution of subduction zones and associated magmatic arcs that accommodated India-Asia convergence (Westerweel et al., 2019). Myanmar is divided into four provinces, from west to east (Fig. 2): (1) the Indo-Burman Ranges, corresponding to the accretionary prism formed in the zone of Indian plate subduction below western Myanmar; (2) the Burma Terrane, forming the bulk of central Myanmar and occupied by late Mesozoic - Cenozoic basins and magmatic rocks; (3) the Mogok-Mandalay-Mergui Belt (MMMB), a roughly N-S trending belt of low- and high-grade metamorphic, ultramafic, and Jurassic to Miocene S-type intrusive rocks; and (4) the Shan-Thai 
Plateau, consisting of Paleozoic and Mesozoic meta-sedimentary rocks attributed to the Sibumasu Terrane of Sundaland (Bender, 1983; Metcalfe, 2013). The origin of the Burma Terrane, its relationship to Tibetan terranes, Sundaland, and the MMMB are very uncertain. Four types of models have been proposed for the origin of the Burma Terrane (Table 1):

Model A. The first family of models proposes that the Burma Terrane belongs to Sundaland since at least the early Mesozoic, either as part of Sibumasu, Cathaysia (remnants of which are found in West Sumatra), or a combination of both. Since the late Triassic, the Burma Terrane built-up as a consequence of the long-term outboard growth of the accretionary prism of Tethyan subduction along he western edge of Sundaland. These models are based on the correlation of Burmese magmatic rocks w1t. their counterparts along the Asian subduction margin (Zhang et al., 2018; 2019; Li et al., 2020) The y are supported by the Cathaysian affinity of some fossil invertebrates found in Burma Terrane P 1 - nz ic limestones (Myint Thein et al., 1982; 1987; Ueno et al., 2016; Metcalfe, 2013). In addition, Sevast ano 7 et al. (2016) argued that U-Pb age distributions of detrital zircons in basement units of th 2 do Burman Ranges --namely the Pane Chaung Formation and Kanpetlet schists-- support an or eral Sibumasu affinity (Sevastjanova et al., 2016); however, this provenance interpretation has been rece $_{{ }_{1}{ }^{+1} \mathrm{~V}}$ challenged by Yao et al. (2017).

Model B. The Burma Terrane is the late an 'ntinuation of the Lhasa Terrane of Tibet (e.g. Mitchell, 1993). This model implies a distinct origin tc. the Burma Terrane and Sundaland, based on the uncertain existence of a suture between the Burma Ten. ${ }^{n}$, and the Shan Plateau, that closed sometime between Jurassic and late

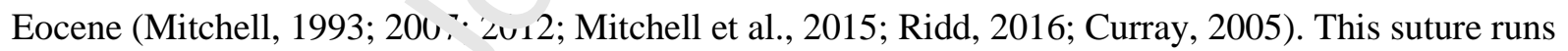
between the Burma Terrane and the MMMB and is represented today by the Myitkyina Ophiolite Belt (MOB, Fig. 2) in north Myanmar (Liu et al., 2016), and/or the cryptic Median Myanmar Suture zone, whose location remains uncertain (Mitchell et al., 2015; Ridd, 2016). The MOB represents the closure of the Mesotethys that separated the Lhasa Terrane from Sibumasu and the Qiangtang Terrane, its western continuation in Tibet (Fig. 1; Liu et al., 2016). A Lhasa affinity for the Burma Terrane is also supported by the presence of an additional ophiolite belt in Myanmar: the Western Ophiolite Belt (WOB; Fig 2), which separates the Burma Terrane from the Indo-Burman Ranges. The nature of the WOB (accretionary or obducted) is not clear (Morley et al., 2020), but the WOB is typically correlated to the Indus-Tsangpo Suture Zone in Tibet (ITSZ; Mitchell, 1993; Mitchell et al., 2012; Liu et al., 2016). The ITSZ ophiolites are 
interpreted as originated and emplaced in a supra-subduction setting along the southern Lhasa margin (Maffione et al., 2015; Wang et al., 2017); the correlation between the WOB and the ITSZ thus supports a Lhasa affinity for the Burma Terrane. Correlations between Burmese and Lhasa magmatic rocks have also been used to argue for this scenario (Mitchell et al., 2012), a correlation that we will address in this study.

Model C. A third family of models proposes that the Burma Terrane and the core of the Indo-Burman Ranges originated along the northern margin of Gondwana and drifted across the Tethys as part of a wide "Greater Argoland" archipelago (Argoland referring to Gondwana-derived rocks in East Java and Sulawesi; Hall et al., 2009), before becoming an intra-oceanic arc (Morley et al., 2020). This Gondwanan origin is supported by an alternate interpretation of $\mathrm{U}-\mathrm{Pb}$ age distributions of detrital zircon $\mathrm{fro}_{\mathrm{n}}$ ? basement units in the IndoBurman Ranges, interpreted as similar to several Gondwanan units ' v n $^{\prime}$ in the Himalayas (Yao et al., 2017). This model is also supported by paleomagnetic data that ic ate the Burma Terrane far from the Asian margin at $100 \mathrm{Ma}$, as part of an intra-oceanic Transtethyan Ar nr ssibly correlative with the Kohistan Arc in Tibet or the Woyla arc of Sumatra (Westerweel et al., $\left.2^{(} 1^{\mathrm{C}}\right)$. This model is, however, contradicted by the Cathaysian affinity of Burma Terrane Paleozoic 'anı sto' es (Table 1).

Model D: The final family of models hypotl rsizes that western Myanmar is an assembly of at least two terranes: a western block composed of the $\mathrm{o}^{\prime} \mathrm{e} . \mathrm{f}$ the Indo-Burman Ranges, including its basement units, named the Mount Victoria Block (Mitc: ell, 1986; 1993; Mitchell et al., 2010; Acharyya, 2007, 2015; Maurin and Rangin, 2009; Rangin, 2018), anı ${ }^{1}$ the Burma Terrane itself, separated by the WOB. In these models, the Mount Victoria Block is eithe par of the Greater Argoland archipelago or a small fragment of India (Mitchell, 1981; Rangin, 2018). The Burma Terrane originated either as an intra-oceanic arc, or along the southern margin of Sundaland, as a correlative to West Sumatra, where Cathaysian fragments are present (Barber and Crow, 2009; Metcalfe, 2013) and later separated from the Asian margin by back-arc spreading, during the episode of WOB and ITSZ ophiolite formation (Gibbons et al., 2015). The Mount Victoria Block and the Burma Terrane collided at low latitudes during the Cretaceous (Morley et al., 2020). More complex variations of this model with multiple blocks for the Burma Terrane basement have also been suggested (Ridd et al., 2019; Aitchinson et al., 2019). There is, as yet, no clear evidence of thickened crust reflecting accreted continental lithosphere around the Mount Victoria Block (Morley et al., 2020).

These models imply significantly different scenarios for the evolution of magmatism in Myanmar (Table 1). 
Two parallel magmatic belts extend N-S in Myanmar, following the Burmese subduction margin, with different history and chronology: To the east, the Dianxi-Shan Scarp-Mergui Granite Belt, part of the "Tin Belt" of Southeast Asia, spanning across the MMMB and mostly comprised of S-type granites, and to the west, the Wuntho-Popa Arc (WPA), part of the Southeast Asian "Copper Belt", extending across the Burma Terrane (Gardiner et al., 2016; 2017). The history of magmatism along the DSMGB has been thoroughly documented (Zaw, 1990; Barley et al., 2003; Searle et al., 2007; 2020; Mitchell et al., 2012; Zhang et al., 2018; Lin et al., 2019); data from the WPA are rarer, but suggest periods of coeval magmatism in both belts (Zhang et al., 2017a; Gardiner et al., 2017; Li et al.,2019; 2020).

Isotopic and geochronological correlations have been used to propose that bu the WPA and DSMGB represent the southeastward continuation of Tibetan arcs across the a ${ }^{+}{ }^{+}{ }_{11}$ Himalayan Syntaxis (Fig. 1; Zhang et al., 2017a; 2019; Lin et al., 2019; Li et al., 2020). The V.'PA shares a similar depleted isotopic signature in $\mathrm{Nd}, \mathrm{Sr}$, and $\mathrm{Hf}$ isotopes with the Gangdese Arc or he Lhasa Terrane and the easternmost Gangdese plutons in the eastern Himalayan syntaxis, th I st it Batholith (Wang et al., 2014; Zhang et al., 2017a; Lin et al., 2019). By contrast, the $\mathrm{DMSG}^{r}$, s. are a similar enriched isotopic signature with the Northern Lhasa Plutonic Belt and its continuation $1 \mathrm{w}^{\text {the }}$ eastern Himalayan syntaxis, the Bomi-Chayu

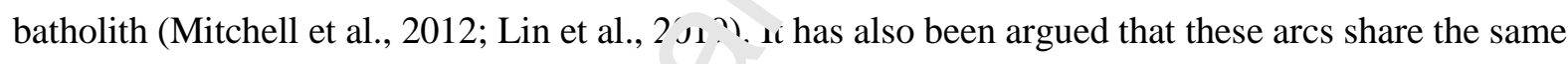
episodes of magmatic flare-ups and lull. (e.c Zhang et al., 2019; Li et al., 2020).

Some studies have proposed that the PS.MGB and WPA reflect different coeval melts (Gardiner et al., 2015; 2017) and periods of advance Ind atreat of the same Andean-type Arc (Zhang et al., 2018), similar to the Gangdese Arc and Northern Lh sa Plutonic Belt (Chapman et al., 2017; Alexander et al., 2019). Other studies have proposed that the belts correspond to two different arcs accreted during the late CretaceousPaleogene (Jagoutz et al., 2015; Westerweel et al., 2019). Understanding the age and geochemical relationship between these arcs and their relationship with Tibetan arcs would help us decipher the origin of the Burma Terrane. However, this is hampered by the lack of geochronological and isotopic data from both areas, particularly from the WPA which is poorly exposed and hard to access.

The paper investigates the magmatic history of the WPA in the Wuntho Ranges, where it is most exposed. We provide new zircon and apatite $\mathrm{U}-\mathrm{Pb}$ ages, apatite fission-track ages, $\mathrm{Nd}-\mathrm{Sr}$ isotopic ratios and elemental composition of rocks from the WPA. We then compare the WPA with the DSMGB and the Tibetan arcs, 
discuss the potential correlation between Tibetan and Burmese magmatic rocks, and apply our new data to test the viability of the four models proposed for the origin of the Burma Terrane.

\section{Geological context}

\subsection{Western Myanmar and the Burma Terrane}

The Burma Terrane forms the bulk of western Myanmar and is almost entirely covered by the Central Myanmar Basins, a N-S trending belt of Late Cretaceous - Cenozoic sedimentary basins comprising two lateral troughs of sub-basins located both east (in a backarc position) and west (in a forearc position) of the WPA (Bender, 1983). The basement of the Burma Terrane crops out in sur ral areas (Fig.1): the Wuntho Ranges, where it comprises magmatic rocks of the WPA and Mesozoic ne' amorphic rocks; the Jade Belt and Minwun Ranges, where it is predominantly serpentinite and local y ju_._-bearing metamorphic rocks; and the Tagaung-Myitkyina Belt, Kumon and Katha-Gangaw Range: wht re it is composed of Triassic to Jurassic metasedimentary rocks and Jurassic to Cretaceous mafic pi :tons (Mitchell, 2017).

On its western margin, the Burma Terrane is sep $a_{1}$ ? by the Indo-Burman Ranges, which are interpreted a the accretionary complex produced by subduction of the Indian Plate beneath the Burmese activf It arg,n (Maurin and Rangin 2009; Bannert et al., 2011; Zhang et al., 2017b). This accretionary complex : tars forming after forearc spreading at 120-130 Ma and the subsequent development of the Cerraı Myanmar Basins (Bender, 1983; Pivnik et al., 1998; Liu et al., 2016; Zhang et al, 2017b), but subdur $:$ ` u uuld have started earlier (Zhang et al., 2018). Most of the Indo-Burman Ranges consist of Neogene hi nalayan-sourced clastic sequences, but the inner wedge of the range comprises early Cretaceous ophiolites of the WOB, Triassic metasediments that are covered by the Orbitolina-bearing Paung Chaung Limestone, and Upper Cretaceous - Eocene marine turbidites (Maurin and Rangin, 2009; Bannert et al., 2011). The Paung Chaung Limestone is widespread on the Burma Terrane, and dated as Upper Albian-Cenomanian (Mitchell, 1993; Bannert et al., 2011). The origin of the Triassic metasediments is uncertain (Sevastjanova et al., 2016, Yao et al., 2017); they may have formed an independent continental fragment that accreted to the Burmese accretionary complex before the Upper Albian (see review in Morley et al., 2020).

The eastern margin of the Burma Terrane and its transition to the MMMB is marked by MOB ultramafics in 
northern Myanmar. In the south, this transition is hidden by Neogene fluvial deposits and is marked by the trace of the Sagaing Fault (Fig. 2). The MMMB is a $2000-\mathrm{km}$ long belt of high-grade metamorphic rocks; metamorphism is thought to start in the Cretaceous and reached its peak between 45-25 Ma (Searle et al., 2007; 2020); MMMB rocks were later exhumed during the Oligo-Miocene (Bertrand et al., 2001; Bertrand and Rangin 2003). The MMMB has been interpreted as the western margin of Sibumasu but it is not clear when and if the Burma Terrane collided with the MMMB. Various unconstrained age estimates for collision have been proposed, ranging from Triassic to Miocene, and the existence of a suture represented by the MOB between both blocks has even been challenged (Mitchell, 1993; Metcalfe, 2013; Sevastjovna et al., 2016; Zhang et al., 2018; Westerweel et al., 2019; Morley et al., 2020). Tı MMMB includes the Jurassic to Miocene plutons of the DSMGB (Bertrand and Rangin 2003; Mitchell ` ${ }^{2}{ }^{1} .2007,2012$; Searle et al., 2012; Liu et al., 2016). The DSMGB includes plutons of the Dianxi Bai non... in northern Myanmar and Yunnan, Shan Scarp plutons in central Myanmar and the Mergui intru 'ves n southern Myanmar (Fig. 2). Zircon U$\mathrm{Pb}$ dating of the DSMGB yielded igneous ages at 170 N ia in central Myanmar (Barley et al., 2003; Searle et al., 2020), 130-110 Ma in central Myanmar and the L ' nxi Batholith, forming the Cretaceous MondaungLawa Arc of Mitchell et al. (2020), 85-40 Ma for $\mathrm{i} \cdot$ e most widespread plutons all along the DSMGB, and a final 25-17 Ma magmatic event in central Mvan. 'ar (Fig. 2; Mitchell et al., 2012; Gardiner et al., 2017, 2018; Zhang et al., 2018). All of them $\mathrm{s}^{\mathrm{v}} . \mathrm{v}$ v zuchemical evidence for some crustal contamination, with low $\varepsilon N d(<0)$, zircon $\varepsilon \mathrm{Hf},(<0)$ and high ${ }^{\circ} \mathrm{Sr} /^{8 \mathrm{u}}$ sr isotopic ratios (>0.7065; Zaw, 1990; Mitchell et al., 2012; Gardiner et al., 2017; Lin et al., 2v:9) Jurassic and Cretaceous plutons are almost all foliated, whereas

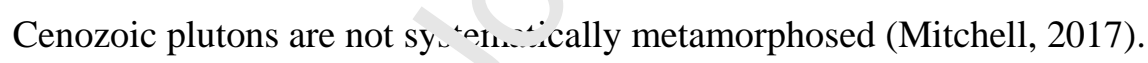

The Cenozoic deformation regime of Myanmar is a result of the hyper-oblique convergence of the Indian Plate below the Burmese margin that drags western Myanmar northwards (Socquet et al., 2006; Rangin et al., 2009; Morley, 2009). Since at least the Oligocene, the Sagaing Fault along the MMMB and the later opening of the Andaman Sea, between Myanmar and Sumatra, have accommodated the strike-slip motion (Morley and Arboit, 2019; Westerweel et al., 2019). The total dextral displacement of central Myanmar, today a forearc sliver since the establishment of the Sagaing Fault along its modern trace, has been variously estimated at 300-400 km to more than 2000 km (Mitchell, 1993; Curray, 2005; Zhang et al., 2018; Westerweel et al., 2019). 


\subsection{The Wuntho-Popa Arc}

The WPA consists of isolated Quaternary volcanoes and crater lakes spread over a 1000 km N-S trend in western Myanmar (Mounts Popa, Taungtalon, Loimye, and Monywa crater lakes) and Pre-Quaternary igneous rocks. The youngest magmatic event is dated to the early Holocene and early to middle Pleistocene (Maury et al., 2004; Lee et al., 2016; Belousov et al., 2018). Quaternary and pre-Quaternary rocks of the WPA display low Sr isotopic ratios $\left({ }^{87} \mathrm{Sr} /{ }^{86} \mathrm{Sr}<0.708\right)$, high $\varepsilon N d$ and zircon $\varepsilon H f$ values $(>0$; Mitchell et al., 2012; Zhang et al., 2017; Gardiner et al., 2017; Lin et al., 2019), which barely overlap with the more enriched isotopic values of the DSMGB rocks.

In central Myanmar, Pre-quaternary WPA rocks are barely exposed an $₫ \mathrm{cc}\urcorner$ sist of isolated intrusives (Fig. 2), and poorly exposed schists and gneiss near Monywa (Mitchell, $: 01$, I. In northern Myanmar, where deeply buried rocks have been exhumed along splays of the Sa a $i_{1_{c}}$ Fault, pre-Quaternary rocks attributed to the WPA and the basement of the Burma Terrane are exposer in the Tagaung-Myitkyina Belt and surrounding ranges (Kumon and Katha-Gangaw), the Ia I, B :lt, and Minwun Range (Fig. 2; Mitchell, 2017). We cannot yet exclude that these areas are indiv duc. blocks of different origin subsequently accreted together (Ridd et al., 2019). The geology of hese areas is described below.

In the Tagaung-Myitkyina Belt, WPA and 3 irr ia Terrane basement rocks include the Jurassic to lower Cretaceous Ngapyawdaw Chaung Fo ma: on, consisting of basalts, andesitic flows, rhyolitic tuffs and volcaniclastics, as well as isolater Jur sic (?) gabbros, diorites, and dacites (Mitchell 2017), including one dacite dated at $171 \mathrm{Ma}\left(\mathrm{G}^{\wedge}{ }^{\mathrm{di}} \mathrm{i}\right.$ er el al., 2018). North of the Tagaung-Myitkyina Belt, exposure of basement rocks continues in the less stיd ¿d Katha-Gangaw and Kumon Ranges (Mitchell, 2017). To the south, the Tagaung-Myitkyina Belt grades into the MOB, and the relationship between both belts is not clear. Zhang et al (2018) reject the ophiolitic nature of the MOB and consider all MOB rocks as belonging to the TagaungMyitkyina Belt, whereas Liu et al (2016) make a clear distinction between these rocks. Diorites near Myitkyina at 171-173 Ma (Liu et al., 2016) are the oldest dated rocks attributed to the WPA (Mitchell, 2017). The nearby Sodon Batholith, at the transition between the Tagaung-Myitkyina Belt and MMMB, has been assigned to the WPA due to its relatively depleted Hf isotope signature (zircon $\varepsilon \mathrm{Hf}$ values between -5 and +10$)$ and has been dated at $51 \mathrm{Ma}$ (Lin et al., 2019).In the Jade Belt, WPA rocks include mafic volcaniclastics in the Jurassic to lower Cretaceous (?) Mawlin Formation and undated diorites (Mitchell, 
2017). Jade-bearing metamorphic rocks in the Jade Belt are serpentinites in which jadeite occurs as dykes or veins, and are attributed to the WPA; they have yielded ages of 160-163 Ma (Shi et al., 2008; Yui et al., 2013); metamorphic overgrowth in the same zircons was dated at $77 \mathrm{Ma}$ (Shui et al., 2013).

The Minwun Range, located between the Wuntho Ranges and the Sagaing Fault, exposes patches of Paleozoic and Mesozoic rocks attributed to the Burma Terrane basement and unconformably covered by Cenozoic clastic rocks (Myint Thein et al., 1982; 1987; 2015). They include undated serpentinites, crystalline rocks called the Mayathein Metamorphics which comprise gneisses, schists, migmatites, calcsilicates, marbles and rare amphibolites, overlain to the west by disconti wous outcrops of Permian and Carboniferous limestones, which in turn are overlain by the Kywethe ( hau g Limestones, highly silicified volcanic rocks, and Jurassic-Cretaceous metasedimentary rocks ter ativ ly correlated to the Ngapyawdaw Chaung Formation of the Tagaung-Myitkyina Belt (United Nans, 1979; Myint Thein et al., 1987). These limestones are typically highly sheared and folded, suggestin, th ${ }^{i}$ incorporation in a paleo-shear zone predating the Sagaing Fault (Myint Thein et al., 2015) l. so ne places the Permian limestone has yielded fossils that include bryozoan, brachiopods, crin $1 \mathrm{~d}$ s ems, and fusulinids (Myint Thein et al., 1987; Ueno et al., 2016). Significantly for paleogeographic : aconstructions, the fauna in the Carboniferous sequence has warm water affinity (Myint Thein et al., 15 37); ecent investigations of the Permian limestones indicate they too formed in a warm water environme ${ }^{`}$ and display biogeographic affinities with Cathaysia and West Sumatra limestones (Barber and Crov. 2009; Ueno et al., 2016).

In central western Myanm. $\cdot \mathrm{t}_{1}$, W PA straddles the middle of the Central Myanmar Basins (Fig. 2); preQuaternary rocks are coverec ${ }^{h} y$ Neogene fluvial sediment in most places. Granites and andesites sampled by oil and gas exploration wells have been dated at 64-69 Ma (Zhang et al., 2017) and 102-106 Ma (Li et al., 2013; Zhang et al., 2017). When exposed, pre-Quaternary rocks comprise I-type batholiths and andesitic bodies punctuated with rarer S-type intrusions. Small intrusives are exposed around Mount Popa, Monywa, and Salingyi and consist of felsic intrusives dated at 13-15 Ma (Mitchell et al., 2012; Lee et al., 2016; Lin et al., 2019) and 98-105 Ma (Mitchell et al., 2012; Gardiner et al., 2017). Directly west of the Shan Scarp, the Mokpalin granite, dated at $91 \mathrm{Ma}$ (Mitchell et al., 2012), has also been attributed to the WPA as it exhibits a characteristic depleted isotopic signature (Lin et al., 2019). The largest exposure of WPA rocks is found in the Wuntho Ranges, the target area of this study. 
The Wuntho Ranges are a 150-km long N-S trending belt of rugged terrain, with elevations up to $1300 \mathrm{~m}$, covered by dense forests. Igneous rocks are exposed along river beds and in isolated quarries. A simplified geological map is provided in Fig. 3, and the regional stratigraphy in Fig. 4. The oldest units of the Wuntho Ranges are the Shwedaung Formation, made of chlorite schists, tremolite schists, silicic tuffs, and the Hpyu Taung Metamorphics, consisting of gneisses, mica schists, and amphibolites (Mitchell, 2017). The age of these units is unknown; Mitchell (2017) correlates these units to Triassic (?) metamorphic rocks found as basement in the Jade Belt and Tagaung-Myitkyina Belt. They form the exposed metamorphic root of the Burma Terrane and have been proposed as a source and/or a lateral extension of the Upper Triassic metasediment in the Indo-Burman Ranges (United Nations, 1978; Sevast,a.'nva et al., 2016).

The Mawgyi Volcanics, Maingthon Dacite, and Mawlin Formation «t the oldest volcanogenic units of the Wuntho Ranges. The Mawgyi Volcanics comprise augite basalts . nd basaltic andesites, with rare pillow lavas, sills and dykes. The Mawlin Formation is composed of alr aniclastics and less common andesite flows that are affected in places by low-grade metamorr ni $m$ and hydrothermal alteration (Westerweel et al., 2019). They are intruded by the Maingthon Dacit $\bullet$. The : ge of these three units is uncertain, but they are regionally correlated with the Jurassic to middle Cru aceous Ngapyawdaw Chaung Formation in the Tagaung-Myitkyina Belt and the igneous p o litı of the Jade Belt which dates back to middle Jurassic (Mitchell, 2017). The only two publish $\mathrm{d}_{\mathrm{s}} \mathrm{a}^{2}$ ' from the Mawgyi Volcanics are one whole rock Ar-Ar age of $101 \mathrm{Ma}$ (Westerweel et al., 2019) a`d 乞 ^e uncertain K-Ar age of $71 \mathrm{Ma}$ (United Nations, 1978). These ages are partly younger than overlyi o ani intruding units, and it is possible they were reset by the low-grade metamorphism and hydrother.'al alteration (Westerweel et al., 2019).

The Mawlin Formation is overlain by the Namakauk Limestone and Nankholon Formation, also grouped under the Kondan Chaung Group (United Nations, 1978). The Namakauk Limestone is correlated with the Orbitolina-bearing Paung Chaung Limestone found throughout the Burma Terrane, including in the Jade and Tagaung-Myitkyina Belts, and dated to the Upper Albian - Cenomanian (Mitchell, 2017). The Nankholon Formation includes mudstone, shales, and tuff, and has yielded two whole rock Ar-Ar ages of 91 and $85 \mathrm{Ma}$ (Turonian to Santonian; Westerweel et al., 2019). Similar to the Mawgyi Volcanics, there is evidence for low-grade metamorphism and hydrothermal alteration in this formation which may have reset these Ar-Ar ages (Westerweel et al., 2019). 
The Kanza Chaung Batholith is the best exposed pluton in the Wuntho Ranges and includes gabbros, I-type diorites and granodiorites, as well as 2-mica granites in the northern part of the ranges. This batholith is particularly well dated, with more than thirty U-Pb and Ar-Ar ages spanning 107 to $87 \mathrm{Ma}$ (United Nations, 1978; Barley et al., 2003; Gardiner et al., 2017; Lin et al., 2019; Westerweel et al., 2019; Li et al., 2020). The oldest age is from a gabbro dated at $106.7 \pm 0.5 \mathrm{Ma}$ by zircon U-Pb dating near Shangalon (Li et al., 2020).

The Mansi Gale Group is only exposed at the margins of the Wuntho Ranges and encompasses all younger volcaniclastic units. It is made of tuffs, volcanic conglomerates and volcanogenic sandstones. At the southern margin of the Wuntho Ranges, in the Shangalon area, the Mansi Gale Group is intruded by EoceneOligocene diorites and porphyries associated with copper mineralization anc tated by U-Pb and K-Ar between 40 and $31 \mathrm{Ma}$, with one older K-Ar age at $50 \mathrm{Ma}$ (Barley $\rho_{\text {. a. }}^{\prime} \quad \angle \mathrm{U} 03$; Gardiner et al., 2016; Li et al., 2019). The Mansi Gale Group is covered by the Neogene fluviai ' 'posits of the Mu Group, that laterally grades into thicker Neogene fluvial units (Pegu Group and Irra ${ }^{\prime}{ }^{\prime}{ }_{\star}$ dy Formation) in the Central Myanmar Basins.

The deformation history of the Cenozoic sedim $\epsilon^{\text {ats }} \mathrm{s}$ described in the study of Zhang et al. (2017a), which provides seismic data south of the Wuntho $\Gamma$ ^nges wnere magmatic rocks are buried by Cenozoic sediment. The Cenozoic history of deformation infer ed $t_{1}-m$ the seismic data includes 1 ) Normal faulting predominantly affecting the back-arc $d_{n}$-ing the Late Cretaceous-Oligocene; fault-related section expansion is greatest during the Eocene and $\mathrm{O}_{\iota_{c}}$ 'acene (T8 to T6 seismic horizons); 2) a first unconformity sometime between the middle Eocene ar 1 ea ly Oligocene (between the T6 and T7 horizons) associated with uplift of the arc, which could be related o footwall uplift of the extensional faults at the western boundary of the back-arc, coupled with magmatic activity; 3) An unconformity during the late Oligocene (above T6 horizon), associated with E-W shortening and uplift of the arc; the uplift is concomitant with denudation of the arc and is expressed by a $22 \mathrm{Ma}$ apatite fission-track age in a diorite of the Kanza Chaung Batholith, sampled at the bottom of an oil and gas exploration well (Li et al., 2013); 4) thrusting that post-dates the Miocene-Pliocene boundary (T3 horizon). Some reactivation of normal faults during the Miocene is also inferred.

The only available map of the Wuntho Ranges is low resolution (1:250 000; United Nations, 1978; refined in Mitchell, 2017); most of the ranges are covered by vegetation.

\section{Methods}


We combined two approaches to document the history of the WPA in the Wuntho Ranges. First, we observed freshly exposed igneous rocks in isolated quarries and river beds, where we measured bedding, deformation and sampled for $\mathrm{U}-\mathrm{Pb}$ dating of zircons, $\mathrm{Sr}$ and $\mathrm{Nd}$ isotopic composition and trace element composition. Exposure was poor and fresh rock samples were often hard to get for some units (Paleogene intrusives; 2-mica granite of the Kanza Chaung Batholith). Some of our samples have experienced some degree of weathering; the location and nature of every sample is described in Supplementary Table 2. We particularly focused on units that have not been dated in previous studies, including all the units predating the emplacement of the Kanza Chaung Batholith. Unfortunately, these units are poorly exposed and we were unsuccessful at dating the few sites with decent exposure: many of our sar ${ }_{\perp}$ les from these units, including the Mawlin Formation (two samples), Maingthon Dacite (one sample), Yav vgyi Volcanics (two samples), Nankholon Formation (one sample) and Shwedaung Formation ( addition, we sampled individual rivers draining the ranges fc: zirc $\mathrm{n} \mathrm{U}-\mathrm{Pb}$ dating, apatite fission-track and $\mathrm{U}-\mathrm{Pb}$ dating. This approach allows us to document the $\mathrm{r}_{1 \xi} \geq$ of igneous and exhumation ages where rocks are covered, in the hope of capturing zircons and anal. as from the units that we did not succeed in dating.

\subsection{Bulk elemental composition}

Twenty-three samples were analyzed for $\mathrm{n}$ aj $\mathrm{r}$...ld trace elements. Seven of them were powdered and analyzed using an inductively-coupler-1 Iasma mass-spectrometer (ICP-MS) iCapQ and an ICP-optical emission spectrometer iCap6500 at l- SARM (CRPG, Vandoeuvre les Nancy, France). The remaining sixteen samples were powdere $\mathcal{A}$ an $^{1}$ analyzed both by X-ray fluorescence analysis using a ThermoARL Advant XP+ automated sequen 'al wavelength and by inductively coupled plasma-mass spectrometry using an Agilent 7700 at the GeoAnalytical Lab of Washington State University (USA). Detailed data are available in Supplementary Table 2.

\subsection{Zircon U-Pb dating}

Among all the units we sampled for U-Pb dating, we succeeded in extracting zircons from one granodiorite of the Kanza Chaung Batholith (sample 1 in Fig. 3), one tuff layer from the Maingthon Dacite (sample 2 in Fig. 3) and one volcanic conglomerate of the Mansi Gale Group (sample 3 in Fig. 3). We also sampled sands from eleven rivers draining the Wuntho Ranges. The sampling locations and river drainage basins are shown on Figure 3; with detailed results and GPS coordinates provided in Supplementary Table 3. Detailed 
analytical protocols and information about the data reduction schemes are provided in supplementary File 1. Briefly, zircons were extracted by traditional methods of heavy mineral separation, including concentration with a Holman-Wilfley gravity table, density separation with methylene iodide, and magnetic separation with a Frantz Magnetic separator. U-Pb dates were generated via laser-ablation inductively-coupled-plasma massspectrometry (LA-ICP-MS), using an iCAP-RQ Quadrupole ICP-MS coupled to an Analyte G2 excimer laser at the University of Washington TraceLab facility, with a spot diameter of 25 microns. Data reduction was conducted with Iolite, using their $U_{-} P b_{-}$Geochron4 data reduction scheme to calculate U-Pb dates uncorrected for common lead (Paton et al., 2010). Dating uncertainties for all samples were calculated using a modified version of the method of Matthew and Guest (2017) that takes $1^{\cdot}{ }^{\circ}$ account the impact of ${ }^{207} \mathrm{~Pb}$ beam intensity on date uncertainties (Hortwood et al., 2016). The ten st $a r$ dary zircon reference materials during these sessions yielded deviations from TIMS ages of $<1 \%$ in $\ldots$ s. st cases, and $<2 \%$ otherwise. Ages for the Kanza Chaung Batholith and Maingthon Dacite amp es are weighted means using Tuffzirc (Ludwig, 2003). The final age error calculated for each s.1 ple is the quadratic sum of the uncertainty of Tuffzirc age calculation and of the systematic unc $\mathrm{all}_{1}{ }^{+} \mathrm{v}\left(\sim 2.67 \%\right.$ for the ${ }^{238} \mathrm{U} /{ }^{206} \mathrm{~Pb}$ ratios$)$. Concordia plots for these two samples are also available in Supplen``ntary Table 3.

\subsection{Apatite U-Pb and fission-track dating,}

Detrital apatites were extracted from ri ar saids for apatite U-Pb and fission-track (AFT) dating. Only four samples yielded apatites for dating. ? otı. types of dates were acquired simultaneously in the GeOHeLiS analytical platform (Univ. Rer .es, France), using an ESI NWR193UC Excimer laser coupled to a quadrupole Agilent 7700x ICr MS that is equipped with a dual pumping system to enhance sensitivity (Paquette et al., 2014). A 30 micron spot diameter was used with a repetition rate of $7 \mathrm{~Hz}$ during 30 seconds. Detailed analytical conditions are found in Cogné et al. (2020). Results are synthesized in Table 2, detailed data are available in Supplementary Table 4, Tera-Wasserburg diagrams for U-Pb ages and radial plots for AFT ages in Supplementary File 2.

Data reduction for U-Pb dates was conducted with Iolite (Paton et al., 2011), using the VisualAgeUcomPbine data reduction scheme of Chew et al (2014). Ages were calculated using IsoplotR (Vermeesch, 2018) and correspond to the lower intercept of discordia in Tera-Wasserburg (TW) plots. Initial common lead values $\left({ }^{207} \mathrm{~Pb} /{ }^{206} \mathrm{Pbi}\right)$ were then calculated from the terrestrial $\mathrm{Pb}$ isotope evolution model of Stacey and Kramers 
(1975) for the TW age. A second discordia is anchored on the y-axis of the TW plot to this value. Both anchored and unanchored discordia yielded similar results. The same ${ }^{207} \mathrm{~Pb} /{ }^{206} \mathrm{Pbi}$ value is used in Iolite to calculate a single grain date corrected for common lead (207CorrAge in Supplementary table 4, Chew et al., 2014).

For fission-track dating, spontaneous tracks were revealed by acid etching with $5.5 \mathrm{M} \mathrm{HNO}_{3}$ at $21^{\circ} \mathrm{C}$ for 20 s. The Grain mounting and etching procedures used are similar to the protocol described by Donelick et al. (2005). Fission-track counting was performed using a Zeiss AxioImager Z1m microscope equipped with an Autoscan automated stage system. AFT data were obtained on the same spot as the U-Pb measurements using the protocol of Cogné et al. (2020). Data reduction was conducter. - sin of the Trace_Elements data reduction scheme (Woodhead et al., 20, 1 , Togné et al., 2020) and an in-house spreadsheet. AFT data were plotted in a radial plot to obtain the $\mathrm{A}^{\mathrm{F} T}$ ages using IsoplotR (Vermeesch, 2018).

\subsection{Nd and Sr isotopic composition}

Isotopic ratios for $\mathrm{Sr}$ and $\mathrm{Nd}$ were measured for 1 samples at the University of Washington Isotope Geochemistry Lab using a Nu Instruments muli $i_{1}$ le-collector inductively-coupled-plasma mass spectrometer (MC-ICP-MS). Sr and Nd column separ.: on -e described in Nelson (1995), and MC-ICP-MS analytical procedures follow those in Gaffney c: al. ( 2007 ) for Nd and Brach-Papa et al. (2009) for Sr. Results are summarized Supplementary Table ? trgether with raw data. Errors shown in the table are within-run statistics and represent erro, in th , last significant digits. The external reproducibility at $2 \sigma$ is $\mathrm{Nd}= \pm 40$ ppm; $\mathrm{Sr}= \pm 40 \mathrm{ppm}$. Sr and Nu compositions are normalized to ${ }^{86} \mathrm{Sr} /{ }^{88} \mathrm{Sr}=0.1194$ and ${ }^{146} \mathrm{Nd} /{ }^{144} \mathrm{Nd}=0.7219$. $\varepsilon_{\mathrm{Nd}}(0)$ is a deviation from chondritic ${ }^{144} \mathrm{Nd} /{ }^{143} \mathrm{Nd}=0.512638$ in units of parts per $10^{4}$.

\section{Results}

\subsection{Structural analysis}

We synthesize our bedding and foliation measurements and field observations with previous structural data from United Nations (1978) maps. Regionally, the Shwedaung Formation (Fig. 4) is dominated by approximately N-S striking, sub-vertically dipping bedding and foliations (Fig. 5a). In the 
unconformably overlying Cretaceous volcanic and sedimentary units, the United Nations (1978) maps report regional dips that are mostly between $45^{\circ}$ and $25^{\circ}$, with a regional NE-SW direction which is also the dominant trend of stratigraphic boundaries in the area (Fig. 3) compatible with our observations (Fig. 5b-d). Typically, bedding is difficult to identify in the Mawgyi Volcanics, but we observed bedding-cleavage relationships within andesitic pyroclastic rocks in some quarries. The cleavage strikes in approximately the same direction as bedding, and dips with respect to bedding can be slightly $\left(\mathrm{c} .10^{\circ}\right)$ steeper, shallower, or similar, suggesting that the cleavage is axial planar, and that much of the bedding orientations were acquired during deformation in a predominantly contractional setting (Fig. 5b). The presence of cleavage suggests significant burial, probably to between $150-200^{\circ} \mathrm{C}$ (e.g. Engelder and Marsı.k, 1985). Remagnetizations recognized in the Mawgyi Volcanics also support burial and metam $\mu_{\mathrm{r}}$ hisın related to the emplacement of the Kanza Chaung batholith (Westerweel et al., 2019). Sub-vertic. 1 conjugate strike-slip faults (strike $044^{\circ}$ dextral, and $280^{\circ}$ sinistral) were observed in one quarry in Ma rov . Volcanics; however, their structural context and timing is uncertain. The Mawlin Formation is if ${ }^{\prime}$ ected by a broad NE-SW trending syncline, where dips typically range between 50 and $20^{\circ}$, r ut an $: e$ as high as $70^{\circ}$ (United Nations, 1978).

Further detail on deformation affecting the Cru' aceous units was observed locally around Shangalon, where we recorded structures in roadcuts that revea er extensive thrust and fold structures in the Maingthon Dacite. The unit shows regular, thin (10-30 rin) la..ering, but is highly weathered, and the layering is laterally discontinuous. Open to tight fold and isharmonic folds, with parallel to similar geometries, and wavelengths in the order $\mathrm{c}$ : mc $\mathrm{t}^{+}$ers. $\mathrm{o}$ tens of meters characterize the section. Numerous small thrusts are also present. Some NE-SW trendi ־ bedding was observed, but dominant bedding orientations are NNW-SSE (Fig. 5c). Most thrusts in the section strike NW-SE, although a few are oriented NNE-SSW (Fig. 5e-f). Fold axes and hinges are oriented between N-S and NW-SE trends. The deformation is complex, and in one area, a N-S striking thrust was observed to cross-cut NW-SE trending thrust structures. We were not able to make observations over a large enough area to determine whether such complexities are local features, or part of a more regional pattern. However, we suspect that there are two structural trends present in the Shangalon section, and that the NW-SE trend is older than the N-S to NE-SW trend. Since the Maingthon Dacite is an extrusive sequence, it is possible that the earlier NW-SE trend represents gravity-driven deformation on the slope of a volcanic edifice. However, testing this hypothesis was not possible. 
The Late Cretaceous-Eocene Mansi Gale Group lies unconformably over the earlier sequences, and is broadly folded on NE-SW trending structures (United Nations, 1978). Dips in the Oligocene sedimentary section are variable, particularly close to major N-S trending dextral Cenozoic strike-slip faults. But overall the Oligocene bedding exhibits NNE-SSW to N-S strikes and low $\left(<40^{\circ}\right)$ dips (Fig. 5d). More recent deposits related to the fluvial Mu Group are affected by the same type of deformation found in the Neogene deposits of the Central Myanmar Basins (Pivnik et al., 1998) which comprises intense folding, thrusting and strikeslip faulting close to major fault zones; with increasing distance a range of structures of various orientations have developed, including normal faults, folds and thrusts. Often faults may be related to classic strike-slip R, R', P and Y shear orientations, while folds have en-echelon buckle folu 'rends (e.g. Sylvester 1988). These structures have been related to the regional dextral strike-slip de ${ }^{-r r}$.ation (Pivnik et al., 1998).

\subsection{Major and Trace elements}

Samples from the Mawgyi Volcanics and Mawlin Formation are ephrite to rhyolite in composition (Fig. 6a) and belong to the tholeiite and calc-alkaline series (Fir. \$). Jamples from the Kanza Chaung batholith show gabbro to granite composition, and belong most'y to the tnoleiite series with a few samples belonging to the calc-alkaline series. Samples from Paleogen: intrusives include basaltic-andesite to trachyte compositions and display $\mathrm{K}_{2} \mathrm{O}$ content that varies from $\mathrm{c}$ ' $1 \mathrm{c} \cdot \mathrm{a}^{\prime}$-aline to tholeiitic, as previously observed by Li et al. (2019); one sample taken from a minin $n_{\diamond}$ nit near Shangalon displays unusually low $\mathrm{K}_{2} \mathrm{O}$ and high $\mathrm{SiO}_{2}$ content likely reflecting weathering (-amıple "w" on Fig 6a and 6b).

The Mawgyi and Mawlin 'olc nic amples show no or only slight light rare earth element (LREE) enrichment (Fig. 6c) and no ner,ative Eu anomaly. On extended trace element diagrams (Fig. 6d), they display weak positive $\mathrm{Pb}$ anomalies and negative $\mathrm{Ti}$ anomalies, and depletion of $\mathrm{Nb}$ and $\mathrm{Ta}$ compared to $\mathrm{La}$ and $\mathrm{K}$. These rocks have however been affected by some degree of hydrothermal alteration (Westerweel et al., 2019), likely affecting mobile elements on REE diagrams. Enrichment in LREE is stronger in the Kanza Chaung batholith samples (Fig. 6e), which display more well-marked positive $\mathrm{Pb}$ and negative Ti anomalies, and depletion of $\mathrm{Nb}$ and $\mathrm{Ta}$ (Fig. 6f). Enrichment in LREE, anomalies in $\mathrm{Pb}, \mathrm{Ti}$, and depletion in $\mathrm{Nb}$ and $\mathrm{Ta}$ are even more marked in Paleogene intrusives. Only one sample, from a 2-mica granite of the Cretaceous Kanza Chaung Batholith has a strong Eu anomaly (Fig.6e). A second sample from the 2-mica granite displays an unusually low REE concentration compared to other Kanza Chaung Batholith samples; this 
sample is a river clast and its mineralogy is predominantly quartz.

\subsection{U-Pb zircon ages}

Zircon age distributions of river sands are displayed in Figure 7. Sands from rivers a, b, and c from the Banmauk area (northern part of the ranges, Fig. 3), drain the Mawgyi Volcanics, granodiorites and 2-micas granites of the Kanza Chaung Batholith. River drainages a, b and c have similar age populations that cover the 90 to $110 \mathrm{Ma}$ time interval, with a weighted mean at $\sim 100 \mathrm{Ma}$. The mean square weighted deviation (MSWD) around the weighted mean for the 90 to 110 Ma zircon population, in these and the following samples, is always $>3$ and often $>10$, indicating that this population likf ly includes a mixture of crystals with several crystallization ages (e.g. Table 2). Sands from river d (Pir ebu area, western part of the ranges) display a much broader age population, including some young ( 3( Ma and old (> $1000 \mathrm{Ma}$, not shown) zircons; the drainage basin of river d includes a broad range of " $n_{1 \mathrm{~L}}$ and its western boundary includes the Oligo-Miocene deposits of the Mu Group; it is thus likely tha: Su ne of these grains are reworked from more recent fluvial deposits and do not reflect direct input fro ${ }^{n}$ th $r$ Wuntho Ranges. Sands from rivers e and f of the same area, draining the Mansi Gale Group, ' lair gthon Dacite and Kanza Chaung Batholith, display the same 90-110 Ma population, centered at 10: and $97 \mathrm{Ma}$. Sands from rivers g, h, and i from the Wuntho area (eastern part of the ranges), draining the $\mathrm{M}$ iv $\mathrm{g}_{\mathrm{j}}:$ Volcanics, Triassic metamorphic rocks and Kanza Chaung Batholith, have the same age populatio. centered at 94, 99, and $101 \mathrm{Ma}$. In addition, rivers g and i yielded Pleistocene zircons (three zircons be veen 64 ka to 192 ka; not shown). River i mainly drains Triassic metamorphic rocks and yielde $1 \mathrm{tw}$. Paleogene zircon grains (23 and $57 \mathrm{Ma}$ ) and only one pre-Cretaceous zircon (not shown). River j dra is the Eocene intrusives near the Shangalon area and yielded a population of late Paleogene grains dated between 32 and $47 \mathrm{Ma}$, centered around $38 \mathrm{Ma}$, with a minor older population of 90-110 Ma grains. Finally, sands of river k, draining the Kanza Chaung batholith near Shangalon, have the same 90-110 Ma population, with one late Eocene grain (37 Ma) and two pre-Cretaceous zircons (not shown).

One sample from the Kanza Chaung Batholith has a U-Pb age of $97.1 \pm 2.6 \mathrm{Ma}$ (MSWD = 1.9, $n=33$; location 1 on Fig. 3). A U-Pb age of $105.8 \pm 2.8 \mathrm{Ma}$ (MSWD = 2.6, $n=34$; location 2 on Fig. 3 ) was obtained for a tuff sample from the Maingthon Dacite. Finally, the U-Pb age distribution of the zircons sampled from a volcanic conglomerate layer of the Mansi Gale Group (location 3 on Figure 3) is displayed on Figure 7. 
The sample yielded two early Oligocene zircons U-Pb dated at $31 \mathrm{Ma}$, one at $58 \mathrm{Ma}$, and a broad 90-110 Ma population with two age peaks, at 96 and $103 \mathrm{Ma}$.

\subsection{Apatite U-Pb and fission-track ages}

Apatite U-Pb and fission-track ages of the four river sands that yielded apatites are displayed on TeraWasserburg and radial plots in Supplementary File 2 and synthesized in Table 2, where they are compared with weighted mean of the main population of zircon ages.

Rivers $\mathrm{b}$ and $\mathrm{c}$ from the Banmauk area have consistent unanchored apatite U-Pb mean ages at $~ 93$ and 94 Ma, five million years younger than the weighted mean of the zircon agc ropulation. The MSWD around U$\mathrm{Pb}$ ages is much smaller than for zircon ages, suggesting they represen a s1 gle event. The younger apatite ages and much lower MSWD compared to zircon ages suggest that they represent a homogeneous late cooling age rather than emplacement ages. Apatite and zircon $U-\tau^{h}$ mean ages of sands from river $f$ and $j$ are statistically indistinguishable at $97 \mathrm{Ma}$ and $38 \mathrm{Ma}$.

Apatite fission-track ages range between 39 and $27 \mathrm{~N}$. All samples passed the $\chi 2$ test suggesting that for each sample there is only one age population of $a_{4} \cdot+i t e$, potentially derived from a limited area within the drainage system of each river. The distributinn $\iota^{c}$ AFT ages does not display any clear geographical pattern; for example, neighboring rivers b and c '.w'e ...ean AFT ages that are $12 \mathrm{Myr}$ apart.

\subsection{Nd and $\mathrm{Sr}$ isotopes}

Strontium and Nd isotope dat $\_$are ummarized in Supplementary Table 2 and compared with previously published data from the WPA a ld from the DMSGB (Fig. 8). The long-term trend for Nd-Sr isotopic values in the Wuntho Ranges is towards more enriched values (higher ${ }^{87} \mathrm{Sr}^{86} \mathrm{Sr}_{(\mathrm{i})}$ and lower $\mathrm{eNd}(\mathrm{t})$ becoming more distinct from typical Neotethyan ophiolite isotopic compositions with time (Fig. 8a). Mawlin Formation and Mawgyi Volcanics samples have whole-rock ${ }^{87} \mathrm{Sr}^{86} \mathrm{Sr}_{(\mathrm{i})}$ ratios between 0.704 and 0.705 , and $\varepsilon \mathrm{Nd}_{(\mathrm{t})}$ between +3.4 and +7; Kanza Chaung Batholith samples have ${ }^{87} \mathrm{Sr}^{86} \mathrm{Sr}_{(\mathrm{i})}$ ratios between 0.745 and 0.7056 , and $\varepsilon \mathrm{Nd}_{(\mathrm{t})}$ between +0.7 and +4.7 ; Paleogene intrusives have ${ }^{87} \mathrm{Sr}^{86}{ }^{8 \mathrm{Sr}_{(\mathrm{i})}}$ ratios between 0.753 and 0.7063 , and $\varepsilon \mathrm{Nd}_{(\mathrm{t})}$ between -1.7 and +3.1 . The trend towards more enriched values is even better expressed when data from $\mathrm{Li}$ et al (2019; 2020; Fig. 8a) is included. Neogene and Quaternary volcanic rocks have less enriched isotopic values than Paleogene intrusives and fall within the range of Sr-Nd composition of the ca. 100 Ma Kanza 
Chaung Batholith.

Regardless of their crystallization ages, WPA rocks are always less isotopically enriched than DSMGB rocks (Fig. 8b; Zaw, 1990; Mitchell et al., 2012; Gardiner et al., 2017; Lin et al., 2019). DSMGB rocks display ${ }^{87} \mathrm{Sr}^{86} \mathrm{Sr}_{(\mathrm{i})}$ ratios commonly higher than 0.707 and $\varepsilon N d$ lower than -5 ; they also display a trend toward more enriched values, with many late Cretaceous-Paleogene plutons (90-40 Ma) displaying higher ${ }^{87} \mathrm{Sr}^{86} \mathrm{Sr}_{(\mathrm{i})}$ ratios and lower $\varepsilon N d$ than earlier plutons.

\section{Discussion}

\subsection{Magmatic and deformation history recorded in the Wuntho Range.}

Though weathering (for Paleogene intrusives), and potentially hydr a. armal activity (for the Mawgyi Volcanics and Mawlin Formation), had likely an impact on the ce mposition of some of our samples, trace

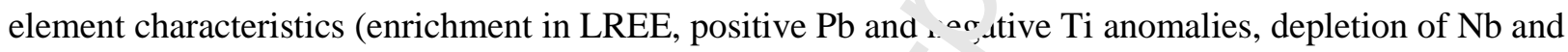
Ta) for all samples analyzed here point to a subduction- el itr $d$ origin for the Wuntho igneous rocks (Hawkesworth et al., 1993). This feature was rec g. 'zę. for the Kanza Chaung plutons by Li et al. (2020) and Shangalon Paleogene intrusives by Li et al. $(26: 9)$; we extended these observations to the earlier Mawlin Formation and Mawgyi Volcanics. All zirc st trans from rivers draining the Mawlin Formation, Maingthon Dacite, and Mawgyi Volcanics yield U- $\mathrm{Pb}$ a.res between 90 and 110 Ma, with no evidence for older age populations. These zircon ages ove:-1ap vith the age range of the Kanza Chaung batholith, as does our new age of 106 Ma for the Maingthr... Daute near Shangalon. Rocks from the Malwin and Mawgyi Volcanics have slightly more depleted $\wedge^{\top}$ and $\mathrm{Sr}$ isotopic signatures than those of the Kanza Chaung Pluton (Fig. 8a). We thus propose that the Mawlin Formation, Maingthon Dacite, and Mawgyi Volcanics are contemporaneous with the early phase Kanza Chaung magmatism ( 105 Ma) and represent the associated volcanic rocks of the oldest Kanza Chaung plutons. We cannot exclude the possibility that the Mawgyi Volcanics extends deeper in time, as proposed for its correlative units in the Jade and Tagaung-Myitkyina Belts (Mitchell, 2017). However, the exposed units of the Mawgyi Volcanics include rocks of andesitic to rhyolitic composition that commonly yield zircons; therefore, the near-absence of pre-110 Ma zircons in the Wuntho river sediments make older ages for these lithologies less likely.

The absence of pre-Cretaceous zircons in river sediments raises questions regarding the nature, age, and 
thickness of the arc metamorphic basement in the Wuntho Ranges. A detailed study of the metamorphic units of the WPA was beyond the scope of our sampling; however, our results show that the correlation between Wuntho Basement units and metamorphosed units of the Jade and Tagaung-Myitkyina Belts (which yield Phanerozoic zircons; Zhang et al., 2018) is not straightforward. These data also eliminate the Wuntho Ranges as a potential source for the pre-Cretaceous zircons found in the Pane Chaung Formation of the IndoBurman Ranges (Sevastjanova et al., 2016) or in the Central Myanmar Basins (Licht et al., 2019).

Neodymium and Sr isotopic compositions show a long-term younging trend towards more enriched values (higher ${ }^{87} \mathrm{Sr}^{86} \mathrm{Sr}_{(\mathrm{i})}$ and lower $\varepsilon \mathrm{Nd}_{(\mathrm{t})}$ ) from the Mawgyi Volcanics to Paleogene intrusives, in parallel with increased LREE enrichment. Neodymium and Sr isotopic compositions $\cap f$ th: Mawgyi Volcanics and Mawlin Formation are particularly depleted but still differ from the a. ate of values found in Neotethyan ophiolites (Fig. 10), indicating some degree of slab-material addı in (slab-derived and/or sediment melts). The increased range and more enriched $\mathrm{Nd}$ and $\mathrm{Sr}$ isotopic con n ${ }^{n}$,itions found in ca. $100 \mathrm{Ma}$ Kanza Chaung plutons and in later Paleogene intrusives indicate a high :r te sree of a subducted component, and/or some assimilation and crustal contamination of the old r s et. norphic basement in the arc lower crust (Chapman et al., 2017). Li et al (2019) interpret the enriched N.'-Sr isotopic values found in Paleogene intrusives to reflect the onset of underthrusting of Indiar c ntilental crust below western Myanmar. Yet, the nature of the crust currently subducted below norther a $N_{\imath}$ ' nnmar (oceanic or thinned continental) is unclear (Steckler et al., 2016). The trend toward more enrıc'ed Nd-Sr isotopic compositions may reflect two other non-exclusive processes:

(1) increased incorporation of $\iota$ dian-derived sediment on the Neotethyan slab into the subduction zone and subsequent incorporation into the slab-component in arc volcanism;

(2) increased crustal assimilation of the arc metamorphic basement due to the thickening of the Burma Terrane.

Miocene and Quaternary volcanic rocks from Mount Popa and Monywa areas have much more depleted Nd and Sr isotope compositions (Fig. 8; Lee et al., 2016). These two volcanic areas are located south of the Wuntho Ranges, where the Burma Terrane crust (Morley et al., 2020) and the offshore sedimentary cover (Curray, 2014) are much thinner. Less crustal assimilation and/or contribution of a slab component can explain the difference between $\mathrm{Sr}$ and $\mathrm{Nd}$ isotope compositions at these southern sites and in the Wuntho 


\section{Ranges.}

Finally, our apatite fission-track data highlight a phase of Paleogene cooling in the WPA. River j, which drains Paleogene intrusives near Shangalon, yielded overlapping AFT, zircon, and apatite U-Pb ages at 35-38 Ma. This indicates that Paleogene intrusives were likely emplaced at much shallower levels than exposed Cretaceous plutons. By contrast, AFT ages are much younger than zircon and apatite $\mathrm{U}-\mathrm{Pb}$ ages for river $\mathrm{b}$ (39 Ma), c (27 Ma) and $\mathrm{f}(31 \mathrm{Ma})$. It is possible that the $39 \mathrm{Ma}$ and $31 \mathrm{Ma}$ AFT ages recorded in river $\mathrm{b}$ and $\mathrm{f}$ resulted from regional thermal resetting following the Paleogene intrusive episode also recorded in river $\mathrm{j}$, though no Paleogene intrusives are recorded in these drainage basins. However, the large difference in AFT ages (ca. $12 \pm 5 \mathrm{Ma}$ ) between the two northern samples (river b and c), dosp ${ }^{\imath} \curvearrowright$ their geographical proximity, is not consistent with regional thermal resetting. We thus interpret $t^{\prime} \backsim \mathrm{AFT}^{\mathrm{N}}$ ages as representing exhumation ages rather than thermal resetting. This phase of exhı mation would have started at least at 39 Ma and can be extended to $22 \mathrm{Ma}$ after including the fission-tı ${ }^{-2}$ age of Li et al (2013) for the Kanza Chaung south of the Wuntho Ranges. This time interval or er'aps with the two phases of uplift of the WPA identified in seismic lines: between the Middle F $\leadsto$ ne and early Oligocene, and in the late Oligocene (Zhang et al., 2017a). This suggests that our apatite :"ssion-track ages and the phase of E-W deformation found in seismic lines all reflect the same $\mathrm{r} . \mathrm{l}$. E Eocene to earliest Miocene deformation events. Comparison of AFT ages between river $\mathrm{b} \mathrm{a}_{1} \mathrm{~d} \mathrm{c}$ suggests that this deformation was diachronous between both sides of the range, though this remains $、$ be confirmed with further sampling.

The difference in intensity anc ork ntation of the bedding measurements between Cretaceous and Cenozoic units, indicate there has to be d formation prior to the Cenozoic, and that deformation has an overall NE-SW to NNE-SSW trend before correction of the $\sim 60^{\circ}$ clockwise rotation indicated by paleomagnetism (Westerweel et al., 2019). The observed NW-SE-striking tilting, folding, and thrusting of Cenozoic beds in the WPA is likely associated with the two Paleogene phases of uplift of the WPA coeval to our apatite fission-track ages, with fold and thrust development likely belonging to the later event, associated with E-W shortening (Zhang et al., 2017a).

\subsection{The WPA: Continuation of the Gangdese Arc? Comparison with the DSMGB and the Lhasa}

\section{Terrane}

The age population of zircons from river sediment derived from the Wuntho Ranges have the same two age 
peaks of $~ 90-108 \mathrm{Ma}$ and 32-46 Ma identified in the crystallization age compilation (Fig 9a, b), as well as river apatites showing $\sim 95 \mathrm{Ma}$ and $\sim 38 \mathrm{Ma} \mathrm{U}-\mathrm{Pb}$ populations. The oldest measured crystallization ages of the WPA are 170-173 Ma in the Tagaung-Myitkyina and Jade Belts; they are coeval with the oldest Mesozoic igneous rocks of the DSMGB (Fig. 9c; Barley et al., 2013; Searle et al., 2020). These early Jurassic igneous ages are not observed in the Wuntho Ranges (oldest age: $107 \mathrm{Ma}$ ), which is noteworthy as it remains unclear if the Tagaung-Myitkyina and Jade Belts are parts of the Burma Terrane (Ridd et al., 2019). WPA crystallization ages at $\sim 50 \mathrm{Ma}$ and $\sim 70 \mathrm{Ma}$ in the Sodon Batholith and below the Eocene sedimentary cover in the central Myanmar (Zhang et al., 2017; Lin et al., 2019) indicate continuous yet more sporadic magmatic activity between the two high-flux events recorded in the Wunu - Ranges, which is not uncommon within subduction-related arcs (Paterson and Ducea, 2015). Th compilation of igneous ages of the WPA and DSMGB show a clear distinction between both arr : Nimg matic lulls in the WPA were associated with magmatic flare-ups in the DSMGB, and vice 'ersc There is no evidence for coeval activity of both arcs based on crystallization ages, unlike claimer.u others (Wang et al., 2014; Gardiner et al., 2015). Wang et al., (2014) and Gardiner et al. (2015) c 'tribute Late Cretaceous - early Paleogene zircons with depleted Hf isotopic signature found in centı. Myanmar Paleogene sediments to WPA igneous activity, but the source of these zircons remains unclear a. they are not found in the Wuntho Ranges. They could be

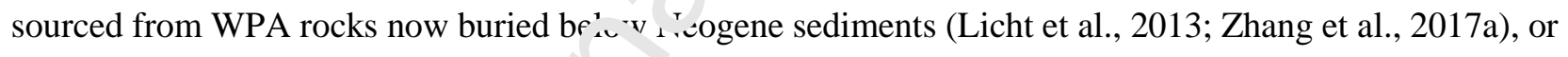
from the eastern Himalayan Syntaxis Robınson et al., 2014).

When compared with Tibetan io. 'ous age compilations, the chronology of magmatism onset, later high-flux events and lulls in the WPA a as not mirror the evolution of the Gangdese Arc, despite claims to the contrary (Zhang et al., 2019, Li et al., 2020). First, none of the oldest igneous ages found in the Wuntho Ranges or in the Tagaung-Myitkyina and Jade Belts are as old as the earliest record of magmatic activity along the Gangdese Arc, where subduction-related magmatism is recorded as early as $210 \mathrm{Ma}$ and was continuous for most of the late Triassic, Jurassic and early Cretaceous (Fig. 9d; Zhu et al., 2019; Kapp and DeCelles, 2019). Later magmatic high-flux events in the WPA seem unrelated to the timing of Gangdese flare-ups; Gangdese flare-ups are either ten million years younger (95-85 Ma) or older (60-52 Ma; Zhu et al., 2019). 
The oldest igneous ages in the DSMGB are roughly coeval with the onset of magmatism along the North Lhasa Plutonic Belt, dated at 180-170 Ma. However, it is hard to draw a firm chronological correlation between both arcs beyond the age of onset. Kapp and DeCelles (2019) identify flare-up events at 115 Ma, $90 \mathrm{Ma}$ and $15 \mathrm{Ma}$ in the North Lhasa Plutonic Belt; the latter two events are obscured by the overrepresentation of $125 \mathrm{Ma}$ igneous ages in our compilation (Fig. 9e). The DSMGB age compilation shows a first peak of igneous ages at $\sim 125 \mathrm{Ma}$, and continuous activity from 90 to $40 \mathrm{Ma}$, without clearly-defined high-flux events during this time window, likely due to an undersampling of the arc.

There is thus no firm ground for a chronological correlation between Tibetan and Burmese arcs. Moreover, the similar isotopic signature in $\mathrm{Nd}, \mathrm{Sr}$, and $\mathrm{Hf}$ shared by arcs of both thace a. eas is not particularly diagnostic, as near-trench arcs share similar depleted signatures wo iu viue (Chapman et al., 2017).

\subsection{Testing the validity of the scenarios for the origin of the $\mathbf{R}_{\mathbf{l}}$. na Terrane}

Our comparison shows that the correlation of magmatic rocks betv.een Myanmar and Tibet proposed to support a Sundaland or a Lhasa origin for the Burma ? er..._. are unfounded (Models A and B, Table 1). However, we do not reject the possibility that ti. 'se arcs have been parts of the same subduction systems in the past. The lack of correlation between Mya.mar and Tibet could reflect along-strike variations of convergence angle, magma addition rates, ar $d r$ ther processes that control arc magmatic tempos along the same subduction margins (Paterson a id L'icea, 2015). In particular, the contrasting magmatic histories of the WPA and DSMGB is compatible with the model proposing a Sundaland origin for the Burma Terrane (Model A, Table 1), in whi $\mathrm{h}$, he tr o arcs are actually part of a single, complex arc developed along the southwestern margin of Suncal and, with periods of advance and retreat (Zhang et al., 2018; Li et al., 2020). Yet, these two models are mainly based on weak magmatic correlations and are therefore less persuasive, particularly since they are contradicted by paleomagnetic data that require the Burma Terrane to be in the southern hemisphere during the Late Cretaceous (Westerweel et al., 2019).

The Greater Argoland and composite models (models C and D), which are compatible with paleomagnetic data, propose different origins for the Burma Terrane but the same Transtethyan nature for the WPA. Multiple models and arcs have been proposed to explain Transtethyan arc rocks (Jagoutz et al., 2015; Kapp and DeCelles, 2019). Catlos et al. (2018) propose onset of intra-oceanic subduction and suprasubduction spreading that started arc activity at around $130 \mathrm{Ma}$, compatible with the oldest crystallization ages and the 
absence of older basement in the Wuntho Ranges and the age of WOB ophiolites. Few crystallization ages are available for comparison with potential candidates for Transtethyan arc rocks, such as the Woyla Arc in Sumatra (Barber et al., 2005; Advokaat et al., 2018) or the Spong Arc in western Tibet (Corfield et al., 2001). The biggest dataset is from the Kohistan Arc (60 ages; Fig. 9g), interpreted to have initially formed as an intra-oceanic arc between around 136 and 120 Ma with continuous magmatic activity from $\sim 120$ Ma to 20 Ma (see review in Petterson, 2019, Searle, 2019), though the oldest pluton of the arc is dated at $154 \mathrm{Ma}$ (Jagoutz et al., 2019). Mid-Cretaceous arc building in Kohistan rocks is locally important (Jijal complex: 118-91 Ma, Sapat Complex: 105-99 Ma, Chilas Complex: 86-81 Ma; Petterson, 2019), with some early Palaeogene volcanism recorded (Bouilhol et al., 2013; Jagoutz et al., 201, Collision with India is generally proposed between around 64 and 42 Ma (e.g. Catlos et al., 2018; Petter an 2019). The Kohistan Arc displays the same long-term isotopic trend from depleted toward noı -nriched values as the WPA, with a more dramatic decrease of $\varepsilon N d$ values and increase of ${ }^{87} \mathrm{Sr}^{86}{ }^{86} \boldsymbol{r}_{(\mathrm{i})} \mathrm{V}$. lues after $50 \mathrm{Ma}$, interpreted as reflecting Kohistan-India collision and onset of Indian crust under+..1. sting (Bouilhol et al., 2013).

The comparison between Transtethyan and WPA $\mathrm{n}_{1} \mathrm{gn}_{1 .}$ tic features and chronology, though based on little data, is thus compatible with the Greater Argoland a. d composite models (models C and D). They are not yet fully satisfactory. The Greater Argolanr. 1 ndei remains inconsistent with the presence of Paleozoic limestones of Cathaysian affinity on the $\mathrm{Bu}$. ๆa Terrane and a potential correlation with West Sumatra (Barber and Crow, 2009). The com?os: ${ }_{1}$ model could reconcile the Cathaysian affinity on the Burma Terrane with the Gondwanan $a^{f_{n} \cdots}$ ity of the Pane Chaung Formation and Kanpetlet Schist in the IndoBurman Ranges as part of the „ostulated Mount Victoria Block (Yao et al., 2017; Morley et al., 2020). The two crustal fragments may have amalgamated during the mid-Cretaceous following the development of the Burma Terrane as an intra-oceanic arc. However, the composite model requires multiple sutures and collision episodes between individual continental fragments for which evidence is elusive. Both models also require a collision and reunification of the Burma Terrane with Sibumasu / Sundaland sometime after 100 Ma, the timing of which remains unconstrained. Late Cretaceous to Eocene (90-40 Ma) plutons of the DSMGB have been interpreted as subduction-related (Zhang et al., 2018a; Gardiner et al., 2017), and metamorphism and deformation along the DSMGB and Sibumasu margin have been proposed to reflect collision and underthrusting of continental crust below Sibumasu since at least $45 \mathrm{Ma}$ (Sautter et al., 2019; 
Searle et al., 2020). Paleomagnetic constraints (Westerweel et al., 2019) show low latitudes during the Eocene, such that a possible BT-Sibumasu collision at 45 Ma may have occurred along the eastern Andaman Sea. It could have reactivated subduction below the WPA, resulting in the magmatic flare-up at 42-36 Ma, with the more recent magmatic events becoming rarer due to the oblique nature of subduction. Yet, this explanation raises issues about the evolution of the Sibumasu margin in the eastern Andaman Sea area, which experienced extension rather than shortening during that time interval (Morley and Alvey, 2015). Our apatite fission-track data show WPA exhumation starting at $39 \mathrm{Ma}$, but the seismic data of Zhang et al. (2017a) instead indicate shortening in the late Oligocene (Zhang et al., 2017a), which could alternatively represent the collision of the northern part of the Burma Terrane with Sibu nasu. However, most of the shortening in the neighboring Central Myanmar Basins is associated wı.h I ate Miocene-Plio-Pleistocene deformation (Pivnik et al., 1998; Ridd and Racey, 2015).

\section{Conclusion}

We show that the WPA in the Wuntho Ranges is char. ctt...ed by only two magmatic events at 46-32 Ma and 108-90 Ma, possibly extending to a few $\mathrm{m}_{\mathrm{L}}{ }^{1}{ }^{\mathrm{i}} \mathrm{\textrm {r }} \mathrm{\Omega}$ years before $108 \mathrm{Ma}$ due to our inability to precisely date the most mafic parts of the Mawgyi Volc. nics. We find no evidence for earlier magmatism or earlier zircon ages in basement units, though Jurass : $\mathrm{j}$ gneous ages have been reported in other parts of the Burma Terrane. Consistent with previous wo k (-ardiner et al., 2018; Li et al., 2019; 2020), we show that magmatism is subduction-related for $\mathrm{b}$, th these events, and is characterized by a depleted $\mathrm{Nd}$ and $\mathrm{Sr}$ isotopic signature that tends towarc' mc 'e er riched values through time. We explain this isotopic trend either by increased incorporation of Indir $n$-derived sediment of the Bengal Basin into the subduction zone or by increased crustal assimilation due to the long-term thickening of the Burma Terrane crust. Apatite fissiontrack data and field measurements, together with previous seismic imaging of the WPA (Zhang et al., 2017b) indicate arc exhumation during 39 to $22 \mathrm{Ma}$, overlapping with the last magmatic event and a subsequent phase of E-W shortening.

By comparing Tibetan and Burmese igneous rock ages, we find no support for a correlation between the Gangdese Arc and the WPA, as argued by models associating the Burma Terrane with Sundaland or the Lhasa Terrane. We show that models proposing an intra-oceanic origin for the WPA are both compatible with the magmatic history of the Wuntho Ranges and supported by paleomagnetic data, though not 
completely satisfactory. The lack of available structural data to constrain the relationships between the different regions of Myanmar, leaves considerable room for further interpretation regarding the origin of the terrane.

\section{Acknowledgments}

This research was primarily funded by the ERC consolidator grant MAGIC 649081 and the University of Washington. We thank Kyi Kyi Thein, Kyaing Sein, D. Cowan, D. van Hinsbergen, M. Mueller, A. Gagnon, M. Pecha, G. Gehrels, and F. Teng for prolific discussions, and assistance i the field and in the lab. This paper benefited from careful reviews by A.J. Barber and A. Mitchell.

\section{Supplementary material}

Supplementary files and tables should be available on.... at:

http://dx.doi.org/10.17632/kvn52xh7hs.2

(still under validation at the time of subms ion)

Supplementary file 1: Analytical methods $\mathrm{f}, \mathrm{r} J-\mathrm{Pb}$ dating at the University of Washington.

Supplementary file 2: Supplementar $/ 1_{\llcorner}{ }^{\top}$ IIres (Apatite U-Pb and AFT plots).

Supplementary table 1: Compilation of igneous ages, $\mathrm{Nd}$ and $\mathrm{Sr}$ data for Myanmar.

Supplementary table 2: Majı r, T1 tce Elements, Nd and Sr isotopic data.

Supplementary table 3: Zircor U-Pb data and Concordia diagrams.

Supplementary table 4: Apatite U-Pb and AFT data.

\section{Figure Captions}

Figure 1 (1 column). Schematic map of South and East Asia with major blocks (LT: Lhasa Terrane, QT:

Qiangtang Terrane; BT: Burma Terrane; ST: Sibumasu Terrane; IB: Indochina Block; SC: South China Block; SG: Songpan Ganzi Complex; WSB: West Sumatra Block) and magmatic arcs addressed in this paper (KA: Kohistan Arc; GA: Gangdese Arc; NLPB: North Lhasa Plutonic Belt; SQT: Southern Qiangtang; WPA: Wuntho-Popa Arc; DSMGB: Dianxi-Shan Scarp-Mergui Granite Belt; WA: Woyla Arc). Red lines 
indicate major faults; red arrows indicate the modern convergence of the Indian Plate. EHS: Eastern Himalayan Syntaxis; ITSZ= Indus-Tsangspo Suture Zone.

Figure 2 (1.5 column). Schematic map of western Myanmar, with the main geological units, after Licht et al. (2019), with published crystallization ages of Mesozoic and Cenozoic magmatic rocks of the WPA and DSMGB (ages in millions of years). Data compilation available in Supplementary Table 1. WR: Wuntho Ranges; JB: Jade Belt; TMB: Tagaung-Myitkyina Belt; WOB: Western Ophiolite Belt; MOB: Myitkyina Ophiolite Belt (dashed blue line); LB: Lohit Batholith; MR: Minwun Range; KR: Kumon and KathaGangaw Ranges.

Figure 3 (1.5 column). Schematic map of the Wuntho Ranges with th $m_{a}$ in geological units, after United Nations (1978), Mitchell (2017) and Westerweel et al (2019). Loca ions of published U-Pb ages of Barley et al., (2003), Gardiner et al $(2016,2017)$, and Li et al. $\left(2019,20^{n n)}\right.$ a.॰ indicated with yellow diamonds (ages in white, in million years). K-Ar ages of United Nations (1979) and U-Pb ages of Lin et al. (2019) are not displayed because they were not published with exact $c \sim$ dj lates. Location of river sands samples in this study are indicated by white dots (black lines: r; rer rainages; letters refer to rivers of Fig. 7); igneous samples for geochemical analysis are indica ${ }^{2} \mathrm{~d}$ by black squares; black squares with numbers are igneous samples dated by zircon $\mathrm{U}-\mathrm{Pb}$ analyses.

Figure 4 (1 column). Stratigraphy in the 'Vuntho Ranges, after Mitchell (2017). Color coding is the same as in Figure 3.

Figure 5 ( 2 columns). Stel $n_{\iota^{+}}$. Aisplaying strikes and dips for bedding, layering and foliation in (a) the Shwedaung Formation, (b) Nıuwgyi Volcanics, Mawlin Formation, Nankholon Formation and Mamakauk Limestone (c) Maingthon Dacite, (d) Upper Eocene - Oligocene outcrops of the Mansi Gale Group near Shangalon (after United Nations, 1978 and our own field measurements). (e) and (f): structures in the Maingthon Dacite near Shangalon (location 2 in Fig. 3).

Figure 6 ( 2 columns). Composition of samples from the Wuntho Ranges: (a) $\mathrm{K} 2 \mathrm{O}+\mathrm{Na} 2 \mathrm{O}$ versus $\mathrm{SiO} 2$ diagram (field for volcanic rocks from Lemaitre et al., 2005; plutonic rocks composition is also plotted for comparison) and (b) $\mathrm{K} 2 \mathrm{O}$ versus $\mathrm{SiO} 2$ diagram (field for magmatic series from Peccerillo and Taylor, 1976); colored areas indicate published data from the Kanza Chaung Batholith (purple; Li et al., 2020) and Paleogene intrusives (orange; Li et al., 2019); sample tagged with letter "w" has been affected by 
weathering. Chondrite- and primitive mantle-normalized element patterns for (c, d) Mawlin and Mawgyi Volcanics, and (e, f) Kanza Chaung batholith and Paleogene intrusives; normalized to elemental concentrations from Sun and McDonough (1989).

Figure 7 (1.5 columns). Age distribution for the eleven modern river sands and a volcanic conglomerate sample from the Mansi Gale Group. See Figure 3 for location. Ages are weighted means over age populations.

Figure 8 ( 2 columns). Whole rock initial Sr-Nd isotopic composition from the WPA (a), including previously published data from Quaternary and Neogene volcanics (Mit hell et al., 2012; Lee et al., 2016), Paleogene intrusives ( $\mathrm{Li}$ et al., 2019) and Kanza Chaung batholith ( $\mathrm{Li}$ i a 2 2020), compared with isotopic composition range of Neotethyan ophiolites from Li et al (2020); P e-K nza Chaung data refer to Mawlin Formation and Mawgyi Volcanics; (b) comparison of WPA $\mathrm{Sr}_{\mathrm{N}} \mathrm{N}$ : otopic data with published data from the DSMGB (Nd-Sr data compilation available in supplementary $\left.\mathbb{T}_{\mathbf{a}} \cdot \mathrm{le} \mathbf{1}\right)$.

Figure 9 ( 1 column). Comparison of (a) Wuntho rive $\mathrm{Zn}_{1}=\mathrm{n} \mathrm{U}-\mathrm{Pb}$ ages (this study), crystallization ages from (b) the WPA and (c) DSMGB (igneous ag. $₹ \mathrm{j}$ cclude Ar-Ar and K-Ar ages, zircon U-Pb ages of individual plutons and intrusives, including $a_{a}{ }^{+}$? from this study). For the WPA, ages coming from the Tagaung-Myitkyina and Jade Belts are displi ye $₫$ in orange. These compilations are compared with those of the (d) Gangdese Arc, (e) North Lhas ı Ł. 'tonic Belt, (f) Southern Qiangtang Arc, and (g) Kohistan Arc. Data for the Gangdese Arc, Nort? Lha a Plutonic Belt, and Southern Qiangtang Arc are from the Tibetan Magmatism Database (Ch`nm 'n ar d Kapp, 2017) purged of redundancies; data from the Kohistan Arc are from Jagoutz et al. (2019). A re compilations are available in Supplementary Table 1. Red shades correspond to the two main age populations identified in the Wuntho Ranges.

Figure 10 (2 columns). Proposed scenario for the evolution of western Myanmar at $95 \mathrm{Ma}$ (a) and $40 \mathrm{Ma}$ (b) for Greater Argoland and composite models (models C and D, Table 1). Reconstruction made with GPlates software adapted from Westerweel et al. (2019). BT: Burma Terrane (in green), WSB: West Sumatra Block (in pink) MVB: Mount Victoria Block (in orange), TH: Tethyan Himalayas, BB: Bengal Bay, KA: Kohistan Arc, QT: Qiangtang Terrane, LT: Lhasa Terrane, KA: Kohistan Arc, SA: Spong Arc; SB: Sibumasu, WA: Woyla Arc, SL: Sundaland. Red lines are transform boundaries. 


\section{Table Captions}

Table 1. The four families of models proposed for the origin of the Burma Terrane. For abbreviations see main text.

Table 2: Synthesis of the U-Pb ages of the zircon main population, apatite U-Pb and fission-track ages for the river sands yielding both apatites and zircons.

\section{References}

Acharyya, S. K. (2007). Collisional emplacement history of í a Ni ga-Andaman ophiolites and the position of the eastern Indian suture. Journal of Asian Earth S - it aces, 29(2), 229-242.

Acharyya, S. K. (2015). Indo-Burma Range: a be ${ }^{1+}$ t a $^{-c}$ creted microcontinents, ophiolites and MesozoicPaleogene flyschoid sediments. International J 'rnal of Earth Sciences, 104(5), 1235-1251.

Advokaat, E. L., Bongers, M. L., Rudyawar, A., QouDagher-Fadel, M. K., Langereis, C. G., \& van Hinsbergen, D. J. (2018). Early Cret « u u origin of the Woyla arc (Sumatra, Indonesia) on the Australian plate. Earth and Plane، rry Science Letters, 498, 348-361.

Alexander, E. W., Wielicki, M. M., H.rrison, T. M., DePaolo, D. J., Zhao, Z. D., \& Zhu, D. C. (2019). Hf and Nd Isotopic Constra. `ts _.. Pre- and Syn- collisional Crustal Thickness of Southern Tibet. Journal of Geophysical Research: solid Earth.

Allen, R., Najman, Y., Carter, A., Barfod, D., Bickle, M.J., Chapman, H.J., Garzanti, E., Vezzoli, G., Ando, S. \& Parrish, R.R. (2008). Provenance of the Tertiary sedimentary rocks of the Indo-Burman Ranges, Burma (Myanmar): Burman arc or Himalayan-derived? Journal of the Geological Society, London, 165, $1045-1057$.

Bannert, D., Lyen, A.S. \& Htay, T. (2011). The Geology of the Indoburman Ranges in Myanmar. Geologisches Jahrbuch, 101, 5-101.

Barber, A. J., \& Crow, M. J. (2009). Structure of Sumatra and its implications for the tectonic assembly of Southeast Asia and the destruction of Paleotethys. Island Arc, 18(1), 3-20. 
Barber, A. J., Crow, M. J., \& Milsom, J. (Eds.). (2005). Sumatra: Geology, resources and tectonic evolution. Geological Society of London.

Barley, M.E., Pickard, A.L., Zaw, K., Rak, P. \& Doyle, M.G. (2003). Jurassic to Miocene magmatism and metamorphism in the Mogok Metamorphic Belt and the India-Eurasia collision in Myanmar. Tectonics, 22, doi:10.1029/2002TC001398.

Belousov, A., Belousova, M., Zaw, K., Streck, M. J., Bindeman, I., Meffre, S., \& Vasconcelos, P. (2018). Holocene eruptions of Mt. Popa, Myanmar: Volcanological evidence of the ongoing subduction of Indian Plate along Arakan Trench. Journal of Volcanology and Geothermal Research, 360, 126-138.

Bender, F. 1983. Geology of Burma. Gebrüder Borntraeger edition, Berliı Stuttgart.

Bellon, H., Maury, R. C., Soeria-Atmadja, R., Cotten, J., \& Polvé, M. ('nn .). 65 my-long magmatic activity in Sumatra (Indonesia), from Paleocene to Present. Bulletin d : la ₹ sciete geologique de France, 175(1), $61-72$.

Bertrand, G., Rangin, C., Maluski, H., Bellon, H. \& GIA _ scientific-Party, (2001), Diachronous cooling along the Mogok Metamorphic Belt (Shan Scarn, ${ }^{\top}$ vanmar): the trace of the northward migration of the Indian syntaxis. Journal of Asian Earth Scienc : 19, 649-659

Bertrand, G., \& Rangin, C. (2003). Tectonic or the western margin of the Shan plateau (central Myanmar): implication for the India-Indochina ' $\varkappa^{\prime} i q_{m}$ convergence since the Oligocene. Journal of Asian Earth Sciences, 21(10), 1139-1157.

Bouilhol, P., Jagoutz, O., Hanchar, I. M., \& Dudas, F. O. (2013). Dating the India-Eurasia collision through arc magmatic records. E. ' ${ }^{\prime} \mathrm{r} \sim$.d Planetary Science Letters, 366, 163-175.

Brach-Papa, C., Van Bocxstaєıe, M., Ponzevera, E., and Quétel, C. R., 2009, Fit for purpose validated method for the determination of the strontium isotopic signature in mineral water samples by multicollector inductively coupled plasma mass spectrometry: Spectrochim. Acta Part B, v. 64, p. 229-234.

Butler, J. P., \& Beaumont, C. (2017). Subduction zone decoupling/retreat modeling explains south Tibet (Xigaze) and other supra-subduction zone ophiolites and their UHP mineral phases. Earth and Planetary Science Letters, 463, 101-117.

Catlos, E. J., Pease, E. C., Dygert, N., Brookfield, M., Schwarz, W. H., Bhutani, R., ... \& Schmitt, A. K. (2019). Nature, age and emplacement of the Spongtang ophiolite, Ladakh, NW India. Journal of the Geological Society, 176(2), 284-305. 
Chapman, J. B., \& Kapp, P. (2017). Tibetan magmatism database. Geochemistry, Geophysics, Geosystems, 18(11), 4229-4234.

Chapman, J. B., Ducea, M. N., Kapp, P., Gehrels, G. E., \& DeCelles, P. G. (2017). Spatial and temporal radiogenic isotopic trends of magmatism in Cordilleran orogens. Gondwana Research, 48, 189-204.

Chew, D.M., Petrus, J.A., and Kamber, B.S., 2014, U-Pb LA-ICPMS dating using accessory mineral standards with variable common Pb: Chemical Geology, v. 363, p. 185-199, doi:10.1016/j.chemgeo.2013.11.006.

Cogné, N., Chew, D. M., Donelick, R. A., \& Ansberque, C. (2020). LA-ICP-MS apatite fission track dating: A practical zeta-based approach. Chemical Geology, 531, 119302.

Corfield, R. I., Searle, M. P., \& Pedersen, R. B. (2001). Tectonic settin ${ }_{\zeta}{ }^{n}{ }^{*}$ gin, and obduction history of the Spontang Ophiolite, Ladakh Himalaya, NW India. The Jourr.l oj Jeology, 109(6), 715-736.

Crow, M. J., Van Waveren, I. M., \& Hasibuan, F. (2019). Tr. geo hemistry, tectonic and palaeogeographic setting of the Karing Volcanic Complex and the Dus a1 aru pluton, an early Permian volcanic-plutonic centre in Sumatra, Indonesia. Journal of Asian $\mathrm{F}_{\mathrm{a}} \cdot \mathrm{h}$ Sciences, 169, 257-283.

Curray, J. R. (2005). Tectonics and history of the ' ndaman Sea region. Journal of Asian Earth Sciences, 25(1), 187-232.

Curray, J. R. (2014). The Bengal deposi i na system: from rift to orogeny. Marine Geology, 352, 59-69.

Ding, L., Zhong, D., Yin, A., Kapp, $\uparrow \quad \&$ Harrison, T. M. (2001). Cenozoic structural and metamorphic evolution of the eastern Himala , ar syntaxis (Namche Barwa). Earth and Planetary Science Letters, 192(3), 423-438.

Donelick, R. A., O’Sullivan, r. B., \& Ketcham, R. A. (2005). Apatite fission-track analysis. Reviews in Mineralogy and Geochemistry, 58(1), 49-94.

Engelder, T. \& Marshak, S. (1985). Disjunctive cleavage formed at shallow depths in sedimentary rocks. Journal of Structural Geology, 7, 327-343.

Gaffney A.M., Blichert-Toft J., Nelson B.K. and Albarède F. (2007) Constraints on source-forming processes of West Greenland kimberlites inferred from Hf-Nd isotope systematics: Geochimica et Cosmochimica Acta, v. 71, p. 2820-2836.

Gardiner, N. J., Searle, M. P., Robb, L. J., \& Morley, C. K. (2015). Neo-Tethyan magmatism and metallogeny in Myanmar-An Andean analogue?. Journal of Asian Earth Sciences, 106, 197-215. 
Gardiner, N. J., Robb, L. J., Morley, C. K., Searle, M. P., Cawood, P. A., Whitehouse, M. J., ... \& Myint, T. A. (2016). The tectonic and metallogenic framework of Myanmar: A Tethyan mineral system. Ore Geology Reviews, 79, 26-45.

Gardiner, N. J., Hawkesworth, C. J., Robb, L. J., Whitehouse, M. J., Roberts, N. M., Kirkland, C. L., \& Evans, N. J. (2017). Contrasting Granite Metallogeny through the Zircon Record: A Case Study from Myanmar. Scientific Reports, 7(1), 748.

Gardiner, N. J., Searle, M. P., Morley, C. K., Robb, L. J., Whitehouse, M. J., Roberts, N. M., ... \& Spencer, C. J. (2018). The crustal architecture of Myanmar imaged through zircon U-Pb, Lu-Hf and O isotopes: Tectonic and metallogenic implications. Gondwana Research, 62, 27-o?

Gibbons, A. D., Zahirovic, S., Müller, R. D., Whittaker, J. M., \& Yatht sh V. (2015). A tectonic model

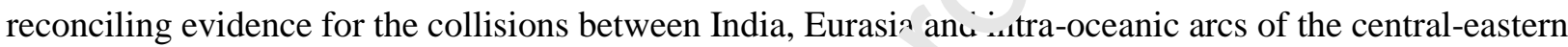
Tethys. Gondwana Research, 28(2), 451-492.

Hall, R., Clements, B., \& Smyth, H. R. (2009). Sundalar «. Jasement character, structure and plate tectonic development.

Hawkesworth, C. J., Gallagher, K., Hergt, J. M., a McDermott, F. (1993). Mantle and slab contributions in arc magmas. Annual Review of Earth and Punetary Sciences, 21(1), 175-204.

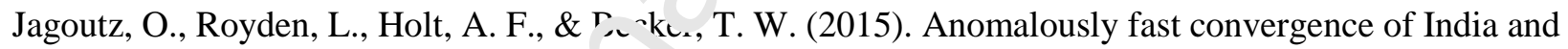
Eurasia caused by double subducı. गn. Nature Geoscience, 8(6), 475-478.

Jagoutz, O., Bouilhol, P., Schalteg ${ }^{\circ}{ }^{\circ}$ U., \& Müntener, O. (2019). The isotopic evolution of the Kohistan Ladakh arc from subduc: ${ }_{1}$ : : iciation to continent arc collision. Geological Society, London, Special Publications, 483(1), 165-182.

Kapp, P., \& DeCelles, P. G. (2019). Mesozoic-Cenozoic geological evolution of the Himalayan-Tibetan orogen and working tectonic hypotheses. American Journal of Science, 319(3), 159-254.

Khan, P. K., \& Chakraborty, P. P. (2005). Two-phase opening of Andaman Sea: a new seismotectonic insight. Earth and Planetary Science Letters, 229(3), 259-271.

Lee, H. Y., Chung, S. L., \& Yang, H. M. (2016). Late Cenozoic volcanism in central Myanmar: Geochemical characteristics and geodynamic significance. Lithos, 245, 174-190.

Le Maitre, R. W., Streckeisen, A., Zanettin, B., Le Bas, M. J., Bonin, B., \& Bateman, P. (Eds.). (2005). Igneous rocks: a classification and glossary of terms: recommendations of the International Union of 
Geological Sciences Subcommission on the Systematics of Igneous Rocks. Cambridge University Press.

Li, R., Mei, L., Zhu, G., Zhao, R., Xu, X., Zhao, H., ... \& Ma, Y. (2013). Late mesozoic to cenozoic tectonic events in volcanic arc, West Burma Block: Evidences from $\mathrm{U}-\mathrm{Pb}$ zircon dating and apatite fission track data of granitoids. Journal of Earth Science, 24(4), 553-568.

Li, J. X., Fan, W. M., Zhang, L. Y., Evans, N. J., Sun, Y. L., Ding, L., ... \& Sein, K. (2019). Geochronology, geochemistry and $\mathrm{Sr}-\mathrm{Nd}-\mathrm{Hf}$ isotopic compositions of Late Cretaceous-Eocene granites in southern Myanmar: Petrogenetic, tectonic and metallogenic implications. Ore Geology Reviews, 112, 103031.

Li, J. X., Fan, W. M., Zhang, L. Y., Peng, T. P., Sun, Y. L., Ding, L., ... \& Sein, K. (2020). Prolonged NeoTethyan magmatic arc in Myanmar: evidence from geochemistry and $\mathrm{s}^{-}-\mathrm{Nd}-\mathrm{Hf}$ isotopes of Cretaceous

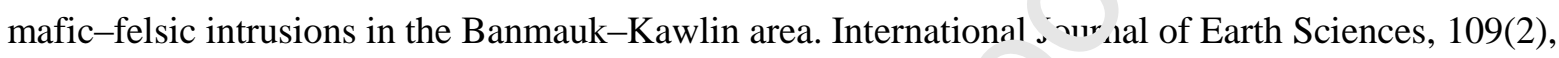
649-668.

Licht, A., France-Lanord, C., Reisberg, L., Fontaine, C., Soe, A. N , \& Jaeger, J. J. (2013). A palaeo TibetMyanmar connection? Reconstructing the Late Eoce ¿` ' Irainage system of central Myanmar using a multi-proxy approach. Journal of the Geologinn1 S, riety, 170(6), 929-939.

Licht, A., Dupont-Nivet, G., Win, Z., Swe, H. H., . aythi, M., Roperch, P., ... \& Jones, D. (2019). Paleogene evolution of the Burmese forearc basin and 1. p plications for the history of India-Asia convergence. Bulletin, 131(5-6), 730-748.

Lin, T. H., Mitchell, A. H., Chung, S. '.., 1 an, X. B., Tang, J. T., Oo, T., \& Wu, F. Y. (2019). Two parallel magmatic belts with contrastin $\underset{\diamond}{ }$ isr topic characteristics from southern Tibet to Myanmar: zircon $\mathrm{U}-\mathrm{Pb}$ and Hf isotopic constran. ‘. : . . rnal of the Geological Society, 176(3), 574-587.

Liu, C. Z., Chung, S. L., Wu, r. Y., Zhang, C., Xu, Y., Wang, J. G., ... \& Guo, S. (2016). Tethyan suturing in Southeast Asia: Zircon U-Pb and Hf-O isotopic constraints from Myanmar ophiolites. Geology, 44(4), $311-314$.

Ludwig, K. R. (2003). Isoplot 3.00: A geochronological toolkit for Microsoft Excel. Berkeley Geochronology Center Special Publication, 4, 70.

Ma, L., Wang, Y., Fan, W., Geng, H., Cai, Y., Zhong, H., Liu, H. \& Xing, X. (2014). Petrogenesis of the early Eocene I-type granites in west Yingjiang (SW Yunnan) and its implication for the eastern extension of the Gangdese batholiths. Gondwana Research, 25, 401-419.

Maffione, M., Van Hinsbergen, D. J., Koornneef, L. M., Guilmette, C., Hodges, K., Borneman, N., ... \& 
Kapp, P. (2015). Forearc hyperextension dismembered the south Tibetan ophiolites. Geology, 43(6), 475478.

Maurin, T. \& Rangin, C. (2009). Structure and kinematics of the Indo-Burmese Wedge: Recent and fast growth of the outer wedge. Tectonics, 28, doi:10.1029/2008TC002276.

Maury, R. C., Pubellier, M., Rangin, C., Wulput, L., Cotten, J., Socquet, A., ... \& Htun, H. M. (2004). Quaternary calc-alkaline and alkaline volcanism in an hyper-oblique convergence setting, central Myanmar and western Yunnan. Bulletin de la Société Géologique de France, 175(5), 461-472.

McCourt, W. J., Crow, M. J., Cobbing, E. J., \& Amin, T. C. (1996). Mesozoic and Cenozoic plutonic evolution of SE Asia: evidence from Sumatra, Indonesia. Geological se -iety, London, Special Publications, 106(1), 321-335.

Metcalfe, I. (2011). Tectonic framework and Phanerozoic evoluti on s. sundaland. Gondwana Research, 19(1), 3-21.

Metcalfe, I. (2013). Gondwana dispersion and Asian acc $\sim$ on: tectonic and palaeogeographic evolution of eastern Tethys. Journal of Asian Earth Sciences a 1-33.

Mitchell, A. H. G. (1981). Phanerozoic plate bouı aries in mainland SE Asia, the Himalayas and Tibet. Journal of the Geological Society, 138(2) に’-122.

Mitchell, A. H. G. (1986). Mesozoic anr' Serı 20 ic regional tectonics and metallogenesis in Mainland SE Asia.

Mitchell, A. H. G. (1993). Cretace ' 's- Cenozoic tectonic events in the western Myanmar (Burma)-Assam region. Journal of the Gu 10: ${ }_{0}$ al Society, 150(6), 1089-1102.

Mitchell, A. H. G., Htay, M. 1., Htun, K. M., Win, M. N., Oo, T., \& Hlaing, T. (2007). Rock relationships in the Mogok metamorphic belt, Tatkon to Mandalay, central Myanmar. Journal of Asian Earth Sciences, 29(5), 891-910.

Mitchell, A. H. G., Hlaing, T., \& Htay, N. (2010). Indo-Myanmar Ranges in the tectonic framework of the Himalaya and Southeast Asia. Indo-Burman Ranges in the Tectonic Framework of the Himalaya and Southeast Asia. Geological Society of India, Memoir, 75, 3-24.

Mitchell, A., Chung, S. L., Oo, T., Lin, T. H., \& Hung, C. H. (2012). Zircon U-Pb ages in Myanmar: Magmatic-metamorphic events and the closure of a neo-Tethys ocean?. Journal of Asian Earth Sciences, $56,1-23$. 
Mitchell, A. H. G., Htay, M. T., \& Htun, K. M. (2015). The medial Myanmar suture zone and the Western Myanmar-Mogok foreland. Journal of the Myanmar Geosciences Society, 6(1), 73-88.

Mitchell, A. (2017). Geological belts, plate boundaries, and mineral deposits in Myanmar. Elsevier. Mitchell, A., Kyaw Min Htun, Myint Thein Htay, Lin, T.H. (2020). Post-Triassic Myanmar west of the Salween: three crustal blocks, two arcs and the Mogok Metamorphics nappe. Journal of the Myanmar Geosciences Society 9, 71-84.

Myint Thien, Maung Maung, Khin Maung Myint, Aye Ko Aung and Khin Aung Than (1982). Geology of the area between Tigyaing and Katha. Research Titles, Natural Science Research Group, Policy Directing Committee on Research Projects, Science and Technology « mmittee, Burma.

Myint Thien, Kan Saw, Aye Ko Aung and Kyaw Tint, (1987). Geolo $z_{:}{ }{ }_{i}$ the area between Tigyaing and Katha. Research Titles, Natural Research Group Burma, 135-:1५.

Myint Thein 2015. The Pre-Tertiary carbonate rocks exposec' tt th : NE margin of the Central Myanmar Basin and their developmental history. Journal of the iv yanmar Geosciences Society, 6, 1-16.

Morley, C. K. (2009). Evolution from an oblique "י bu ction back-arc mobile belt to a highly oblique collisional margin: the Cenozoic tectonic deve: vment of Thailand and eastern Myanmar. Geological Society, London, Special Publications, 318( i’, 373-403.

Morley, C. K., \& Alvey, A. (2015). Is sr ^ ^a...g prolonged, episodic or incipient in the Andaman Sea? Evidence from deepwater sedime. ${ }^{+}$ation. Journal of Asian Earth Sciences, 98, 446-456.

Morley, C. K., \& Arboit, F. (2019). D'ting the onset of motion on the Sagaing fault: Evidence from detrital zircon and titanite $\mathrm{U}-\mathrm{Pb}_{2} \mathrm{ec}^{2}{ }^{2}$. onology.

Morley, C. K., Naing, T. T., searle, M., \& Robinson, S. A. (2020). Structural and tectonic development of the Indo-Burma Ranges. Earth-Science Reviews, 102992.

Nelson B.K. (1995) Fluid flow in subduction zones: Evidence from Nd- and Sr-isotope variations in metabasalts of the Franciscan Complex, California: Contributions to Mineralogy and Petrology, v. 119, p. $247-262$.

Paterson, S. R., \& Ducea, M. N. (2015). Arc magmatic tempos: gathering the evidence. Elements, 11(2), 9198.

Paton, C., Hellstrom, J., Paul, B., Woodhead, J., Hergt, J., 2011. Iolite: Freeware for the visualisation and processing of mass spectrometric data. Journal of Analytical Atomic Spectrometry 26, 2508-2518. 
Paquette, J., Piro, J., Devidal, J., Bosse, V., Didier, A., Sanac, S., Abdelnour, Y., 2014. Sensitivity enhancement in LA-ICP-MS by N2 addition to carrier gas: Application to radiometric dating of U-Thbearing minerals. Agil. ICP-MS J. 58, 1-5.

Peccerillo, A., \& Taylor, S. R. (1976). Geochemistry of Eocene calc-alkaline volcanic rocks from the Kastamonu area, northern Turkey. Contributions to mineralogy and petrology, 58(1), 63-81.

Petterson, M. G. (2019). The plutonic crust of Kohistan and volcanic crust of Kohistan-Ladakh, north Pakistan/India: lessons learned for deep and shallow arc processes. Geological Society, London, Special Publications, 483(1), 123-164.

Pivnik, D., Nahm, J., Tucker, R., Smith, G., NNyein, K.,Nyunt, M. \& Máł`ơ, P. (1998). Polyphase Deformation in a Fore-Arc/Back-Arc Basin, Salin Subbasin, Myanı ar Burma). AAPG Bulletin 82, $1837-1856$.

Rangin, C.,Win Maw, Lwin, S., Naing, W., Mouret, C., Bert*' nd, J. \& the G.I.A.C. (1999). scientific party. Cenozoic pull-apart basins in central Myanmar: the $t^{\top}$ a $\geq$ of the path of India along the western margin of Sundaland. Terra Abstracts (Journal of Conferance Abstracts of the EGU), 4, 59.

Rangin, C. (2018). The Western Sunda Basins ani the India/Asia Collision: An Atlas. Geotecto consulting.

Replumaz, A., Negredo, A. M., Guillot, S., $\&$ V V.1'aseñor, A. (2010). Multiple episodes of continental subduction during India/Asia conver on ${ }^{2}$. Insight from seismic tomography and tectonic reconstruction. Tectonophysics, 483(1), 125-134.

Replumaz, A., Guillot, S., Villaseı `r. A., \& Negredo, A. M. (2013). Amount of Asian lithospheric mantle subducted during the Inc $\urcorner_{1}, \mathfrak{\iota}$ collision. Gondwana Research, 24(3), 936-945.

Robinson, R. A., Brezina, C. A., Parrish, R. R., Horstwood, M. S., Oo, N. W., Bird, M. I., ... \& Zaw, K. (2014). Large rivers and orogens: The evolution of the Yarlung Tsangpo-Irrawaddy system and the eastern Himalayan syntaxis. Gondwana Research, 26(1), 112-121.

Ridd, M. F. (2016). Should Sibumasu be renamed Sibuma? The case for a discrete Gondwana-derived block embracing western Myanmar, upper Peninsular Thailand and NE Sumatra. Journal of the Geological Society, 173(2), 249-264.

Ridd, M. F., \& Racey, A. (2015). Onshore petroleum geology of Myanmar: Central Burma depression. Geological Society, London, Memoirs, 45(1), 21-50.

Ridd, M. F., Crow, M. J., \& Morley, C. K. (2019). The role of strike-slip faulting in the history of the 
Hukawng Block and the Jade Mines Uplift, Myanmar. Proceedings of the Geologists' Association.

Royden, L. H., Burchfiel, B. C., \& van der Hilst, R. D. (2008). The geological evolution of the Tibetan Plateau. science, 321(5892), 1054-1058.

Sautter, B., Pubellier, M., Schlögl, S. K., Matenco, L., Andriessen, P., \& Mathew, M. (2019). Exhumation of west Sundaland: A record of the path of India?. Earth-Science Reviews, 102933.

Searle, M.P., Noble, S.R., Cottle, J.M., Waters, D.J., Mitchell, A.H.G., Hlaing, T. \& Horstwood, M.S.A. (2007). Tectonic evolution of the Mogok Metamorphic Belt, Burma (Myanmar) constrained by U-Th-Pb dating of metamorphic and magmatic rocks. Tectonics, 26, doi:10.1029/2006TC002083.

Searle, M. P., Whitehouse, M. J., Robb, L. J., Ghani, A. A., Hutchison, C. ` . Sone, M., ... \& Oliver, G. J. H. (2012). Tectonic evolution of the Sibumasu-Indochina terrane collı : $n r$ zone in Thailand and Malaysia: constraints from new U-Pb zircon chronology of SE Asian tir gl w.i.ioids. Journal of the Geological Society, 169(4), 489-500.

Searle, M. (2019). Ophiolites and Regional Tectonics. Ir C zology of the Oman Mountains, Eastern Arabia (pp. 85-115). Springer, Cham

Searle, M. P., Garber, J. M., Hacker, B. R., Htun, : , Gardiner, N. J., Waters, D. J., \& Robb, L. J. ( 2020). Timing of syenite- charnockite magmaticm and ruby- and sapphire metamorphism in the Mogok valley region, Myanmar. Tectonics, 39, e20 ’ TL־05998. https://doi.org/10.1029/2019TC005998

Sevastjanova, I., Hall, R., Rittner, M., Paw, S. M. T. L., Naing, T. T., Alderton, D. H., \& Comfort, G. (2016). Myanmar and Asia united, Aus. al a left behind long ago. Gondwana Research, 32, 24-40.

Shi, G., Cui, W., Cao, S., Jlung, ㅍ., Jian, P., Liu, D., ... \& Chu, B. (2008). Ion microprobe zircon U-Pb age and geochemistry of the Mıyanmar jadeitite. Journal of the Geological Society, 165(1), 221-234.

Shen, F., Royden, L. H., \& Burchfiel, B. C. (2001). Large-scale crustal deformation of the Tibetan Plateau. J. geophys. Res, 106(B4), 6793-6816.

Socquet, A., Vigny, C., Chamot- Rooke, N., Simons, W., Rangin, C., \& Ambrosius, B. (2006). India and Sunda plates motion and deformation along their boundary in Myanmar determined by GPS. Journal of Geophysical Research: Solid Earth, 111(B5).

Stacey, J.S., Kramers, J.D., 1975. Approximation of Terrestrial Lead Isotope Evolution by a 2-Stage Model. Earth Planet. Sci. Lett. 26, 207-221.

Steckler, M. S., Mondal, D. R., Akhter, S. H., Seeber, L., Feng, L., Gale, J., ... \& Howe, M. (2016). Locked 
and loading megathrust linked to active subduction beneath the Indo-Burman Ranges. Nature Geoscience, 9(8), 615-618.

Sun, S. S., \& McDonough, W. F. (1989). Chemical and isotopic systematics of oceanic basalts: implications for mantle composition and processes. Geological Society, London, Special Publications, 42(1), 313-345.

Sylvester, A.G., 1988. Strike-slip faults. Geological Society of America Bulletin, 100, 1666-1703.

Ueno, K., Thein, M., \& Barber, A. J. (2016, October). Permian fusuline fauna from the Minwun Range, Central Myanmar. In 5th Symposium of the International Geosciences Programme (IGCP) (Vol. 589, pp. 27-28).

United Nations, 1979. Mineral exploration in selected areas. Technical R $\iota_{\mu}$ רrt No. 6, United Nations Development Programme, DP/UN/BUR-72-002/15, United Nations, N w York, $86 \mathrm{p}$.

United Nations 1978. Geology and Exploration Geochemistry of he : :ulebu- Banmauk Area, Sagaing Division, Northern Burma. Technical Report No.2, Unite Nat ons Development Programme, UN/ BUR72 002/6, United Nations, New York, 69 p.Van Hins'心, gen, D. J., Kapp, P., Dupont- Nivet, G., Lippert, P. C., DeCelles, P. G., \& Torsvik, T. H. (2011 ' R ' toration of Cenozoic deformation in Asia and the size of Greater India. Tectonics, 30(5).

Vermeesch, P., 2018. IsoplotR : A free and nneı +oolbox for geochronology. Geosciences Frontiers, 5, 14791493.

Wang, J., Wu, F., Tan, X. \& Liu, C. '014). Magmatic evolution of the Western Myanmar Arc documented by $\mathrm{U}-\mathrm{Pb}$ and $\mathrm{Hf}$ isotopes in deı. ${ }^{\circ} \mathrm{a}^{\mathrm{l}}$ zircon. Tectonophysics, 612-613, 97-105.

Wang, J. G., Hu, X., Garzaıः ' L., . An, W., \& Liu, X. C. (2017). The birth of the Xigaze forearc basin in southern Tibet. Earth and rlanetary Science Letters, 465, 38-47.

Westerweel, J., Roperch, P., Licht, A., Dupont-Nivet, G., Win, Z., Poblete, F., ... \& Aung, D. W. (2019). Burma Terrane part of the Trans-Tethyan arc during collision with India according to palaeomagnetic data. Nature Geoscience, 12(10), 863-868.

Woodhead, J., Hellstrom, J., Hergt, J., Greig, A. and Maas, R (2007) Isotopic and elemental imaging of geological materials by laser ablation Inductively Coupled Plasma mass spectrometry. Journal of Geostandards and Geoanalytical Research, 31, 331-343.

Yao, W., Ding, L., Cai, F., Wang, H., Xu, Q., \& Zaw, T. (2017). Origin and tectonic evolution of upper Triassic Turbidites in the Indo-Burman ranges, West Myanmar. Tectonophysics, 721, 90-105. 
Yui, T. F., Fukoyama, M., Iizuka, Y., Wu, C. M., Wu, T. W., Liou, J. G., \& Grove, M. (2013). Is Myanmar jadeitite of Jurassic age? A result from incompletely recrystallized inherited zircon. Lithos, 160, 268-282.

Zaw, K. (1990). Geological, petrological and geochemical characteristics of granitoid rocks in Burma: with special reference to the associated W-Sn mineralization and their tectonic setting. Journal of Southeast Asian Earth Sciences, 4(4), 293-335.

Zhang, P., Mei, L., Hu, X., Li, R., Wu, L., Zhou, Z., \& Qiu, H. (2017a). Structures, uplift, and magmatism of the Western Myanmar Arc: Constraints to mid-Cretaceous-Paleogene tectonic evolution of the western Myanmar continental margin. Gondwana Research, 52, 18-38.

Zhang, J. E., Xiao, W., Windley, B. F., Cai, F., Sein, K., \& Naing, S. (201, 'h) Early Cretaceous wedge

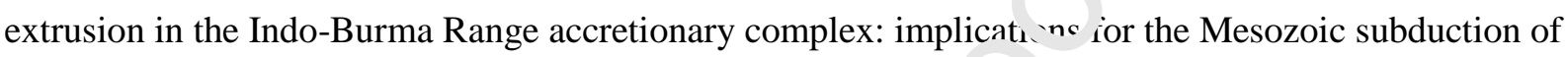
Neotethys in SE Asia. International Journal of Earth Sciences $1-i 0$.

Zhang, J. E., Xiao, W., Windley, B. F., Wakabayashi, J., Cai, F., S sin, K., ... \& Naing, S. (2018). Multiple alternating forearc-and backarc-ward migration of $m$ satism in the Indo-Myanmar Orogenic Belt since the Jurassic: Documentation of the orogenic arnhiı ^ture of eastern Neotethys in SE Asia. Earth-Science Reviews.

Zhang, X., Chung, S. L., Lai, Y. M., Ghani. A. . . Murtadha, S., Lee, H. Y., \& Hsu, C. C. (2019a). A 6000km-long Neo-Tethyan arc system wi... O...rent magmatic flare-ups and lulls in South Asia. Geology, 47(6), 573-576.

Zhang, P., Najman, Y., Mei, L., M.'1lar, I., Sobel, E., Carter, A., ... \& Vezzoli, G. (2019b). Palaeodrainage evolution of the large r1 $\vee^{r}$. $f$ Last Asia, and Himalayan-Tibet tectonics. Earth-science reviews.

Zhu, D. C., Wang, Q., Chung, s. L., Cawood, P. A., \& Zhao, Z. D. (2019). Gangdese magmatism in southern Tibet and India-Asia convergence since 120 Ma. Geological Society, London, Special Publications, 483(1), 583-604. 


\section{Magmatic history of central Myanmar and implications for the evolution of the}

\section{Burma Terrane}

Alexis Licht (1)*, Zaw Win (2), Jan Westerweel (3), Nathan Cogné (3), Chris Morley (4), Sarawute Chantraprasert (4), Fernando Poblete (3,5), Tamas Ugrai (1), Bruce Nelson (1), Day Wa Aung (6) and Guillaume Dupont-Nivet $(3,7,8)$

(2) Department of Earth and Space Sciences, University of Washington. Seattle WA 98195, USA.

(2) Geology Department, Shwe Bo University, Sagaing Region, Myan ıaı .

(3) Géosciences Rennes, UMR CNRS 6118, Univ. Rennes, 3504? ^'enn «s Cedex, France.

(4) PTTEP, Bangkok, Thailand

(5) Departamento de Geología, Universidad de Chile, S nt a 'o, Chile.

(6) Geology Department, University of Yangon Py y Ra, Yangon, Myanmar.

(7) Potsdam University, Institute of Earth anu Environmental Science, 14476 Potsdam, Germany.

(8) Key Laboratory of Orogenic Belts ar ${ }^{\lambda} \mathrm{C} 1$ ral Evolution, Ministry of Education, Beijing, China.

* Corresponding author (e-mail: licht心'ıw.edu)

\section{CRediT author statement}

Alexis Licht: Conceptualization, Methodology, Investigation, Data Curation, Writing - Original Draft, supervision. Zaw Win, Jan Westerweel, Nathan Cogné, Chris Morley, Sarawute Chantraprasert, Fernando Poblete, Tamas Ugrai, Bruce Nelson: Investigation, data curation, Writing - Review \& editing. Day Wa Aung: Supervision, Project administration. Guillaume Dupont-Nivet: Writing- Reviewing and Editing, Supervision, Funding acquisition. 


\section{Declaration of interests}

$\bigotimes$ The authors declare that they have no known competing financial interests or personal relationships that could have appeared to influence the work reported in this paper.

$\square$ The authors declare the following financial interests/personal relationships which may be considered as potential competing interests: 


\begin{tabular}{|c|c|c|c|c|}
\hline $\begin{array}{l}\text { Paleographic models for the } \\
\text { Burma Terrane }\end{array}$ & $\begin{array}{c}\text { Key } \\
\text { Reference }\end{array}$ & Pros & Cons & $\begin{array}{l}\text { Implications for the WPA / } \\
\text { correlation with Tibetan ares }\end{array}$ \\
\hline $\begin{array}{l}\text { A- Conservative models: Burma } \\
\text { Terrane is part of Sundaland }\end{array}$ & $\begin{array}{l}\text { Zhang et } \\
\text { al. (2019) }\end{array}$ & $\begin{array}{l}\text {-Correlation between the WPA and the } \\
\text { Gangdese arc of Tibet } \\
\text {-Cathaysian affinity of Burma Terrane } \\
\text { Paleozoic limestones } \\
\text {-Zircon age distribution of Indo-Burman } \\
\text { Ranges basement showing Sibumasu } \\
\text { affinity }\end{array}$ & $\begin{array}{l}\text {-In disagreement with } \\
\text { paleomagnetic data } \\
\text {-reject the existence of Meso- } \\
\text { Cenozoic suture zones In Myanmar }\end{array}$ & $\begin{array}{l}\text {-Same magmatic history as the one } \\
\text { of the southern Qiangtang Arc } \\
\text { since the early Triassic until } \sim 130 \text { - } \\
120 \text { Ma and the collision of Lhasa } \\
\text { and Qiangtang. } \\
\text {-Similar magmatic history as the } \\
\text { one of the Gangdese Arc after } 120 \\
\text { Ma. }\end{array}$ \\
\hline $\begin{array}{c}\text { B- Burma Terrane is the } \\
\text { easternmost part of the Lhasa } \\
\text { Terrane }\end{array}$ & $\begin{array}{l}\text { Mitchell } \\
\text { (1993) }\end{array}$ & $\begin{array}{l}\text {-Correlation between the WPA and the } \\
\text { Gangdese arc of Tibet } \\
\text {-Correlation between the WOB and ITSZ }\end{array}$ & $\begin{array}{l}\text {-In disagreement with } \\
\text { paleomagnetic data } \\
\text {-In disagreement with the } \\
\text { Cathaysian affinity of Paleozoic } \\
\text { limestones }\end{array}$ & $\begin{array}{l}\text {-Same magmatic history as the one } \\
\text { of the Gangdese Arc since its } \\
\text { creation. }\end{array}$ \\
\hline $\begin{array}{l}\text { C- Burma Terrane is a } \\
\text { Gondwana-derived fragment } \\
\text { (part of Greater Argoland) }\end{array}$ & $\begin{array}{l}\text { Morley et } \\
\text { al. }(2020)\end{array}$ & $\begin{array}{l}\text {-Zircon age distribution of Indo-Burman } \\
\text { Ranges basement showing Gondwana } \\
\text { affinity } \\
\text {-Equatorial paleolatitude of the terrane in } \\
\text { the Cretaceous shown by } \\
\text { paleomagnetism }\end{array}$ & $\begin{array}{l}\text {-Incompatible with suture and arc } \\
\text { correlations } \\
\text {-In disagreement } w \text { h the } \\
\text { Cathaysian aff *o of }, \text { leozoic } \\
\text { limestones }\end{array}$ & $\begin{array}{l}\text {-No direct correlation with Tibet, } \\
\text { but potentially same magmatic } \\
\text { history as the one of the Kohistan } \\
\text { Arc. }\end{array}$ \\
\hline $\begin{array}{l}\text { D- Composite models: Burma } \\
\text { Terrane is a mosaic of collided } \\
\text { fragments }\end{array}$ & $\begin{array}{l}\text { Rangin } \\
(2018)\end{array}$ & $\begin{array}{l}\text {-potentially compatible with all the } \\
\text { above }\end{array}$ & $\begin{array}{l}\text {-No evi ence sr thickened crust at } \\
\text { the loci ion of otential } \\
\text { mic1 con. }\end{array}$ & -no direct correlation with Tibet. \\
\hline
\end{tabular}




\begin{tabular}{|c|c|c|c|}
\hline & \multirow{2}{*}{$\begin{array}{c}\text { weighted mean of main zircon age } \\
\text { population, age }+2 s(\mathrm{Ma})\end{array}$} & Apatites & \\
\cline { 3 - 4 } & & U-Pb ages + 2s (unanchored; Ma) & Fission track ages + 2s (Pooled; Ma) \\
\hline River b & $98.9 \pm 2.7(n=60, M S W D=21)$ & $93.0 \pm 1.6 \quad(n=107, M S W D=0.96)$ & $38.8 \pm 3.0 \quad(p(\chi 2)=0.47, n=107)$ \\
\hline River c & $99.4 \pm 2.6(n=89, M S W D=4.2)$ & $94.4 \pm 1.4 \quad(n=117, M S W D=2.2)$ & $26.6 \pm 1.5 \quad(p(\chi 2)=0.16, n=117)$ \\
\hline River $\mathrm{f}$ & $96.6 \pm 2.6(n=114, M S W D=3.4)$ & $96.7 \pm 7.5 \quad(n=28, M S W D=2.4)$ & $31.0 \pm 4.9 \quad(p(\chi 2)=0.08, n=28)$ \\
\hline River j & $38.2 \pm 1.0(n=98, M S W D=6.3)$ & $38.0 \pm 1.2(n=114, M S W D=1.8)$ & $35.3 \pm 2.3 \quad(p(\chi 2)=0.99, n=114)$ \\
\hline
\end{tabular}


Graphical abstract

\section{Highlights}

- We investigate the history of the Wuntho-Popa Arc (WPA) in the Wuntho Ranges, Myanmar.

- The WPA is characterized by two high-flux events at 108-90 Ma and 46-32 Ma.

- Magmatism is subduction-related for both events.

- We identify two phases of deformation, in the Cretaceous and he 1 te Paleogene.

- Our data are compatible with a Transtethyan Arc origin fo1 the VPA. 


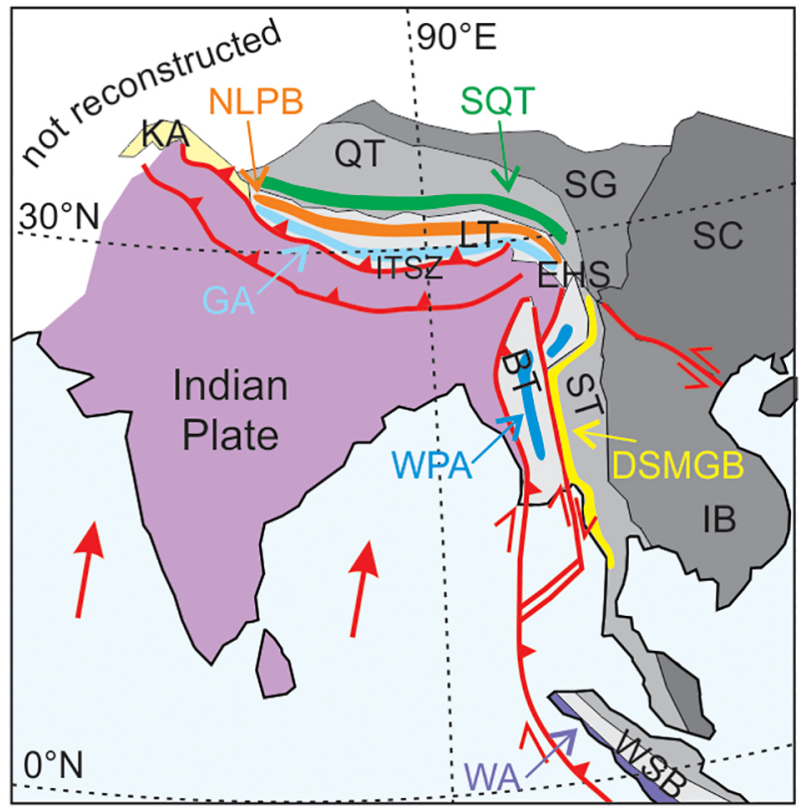

Figure 1 

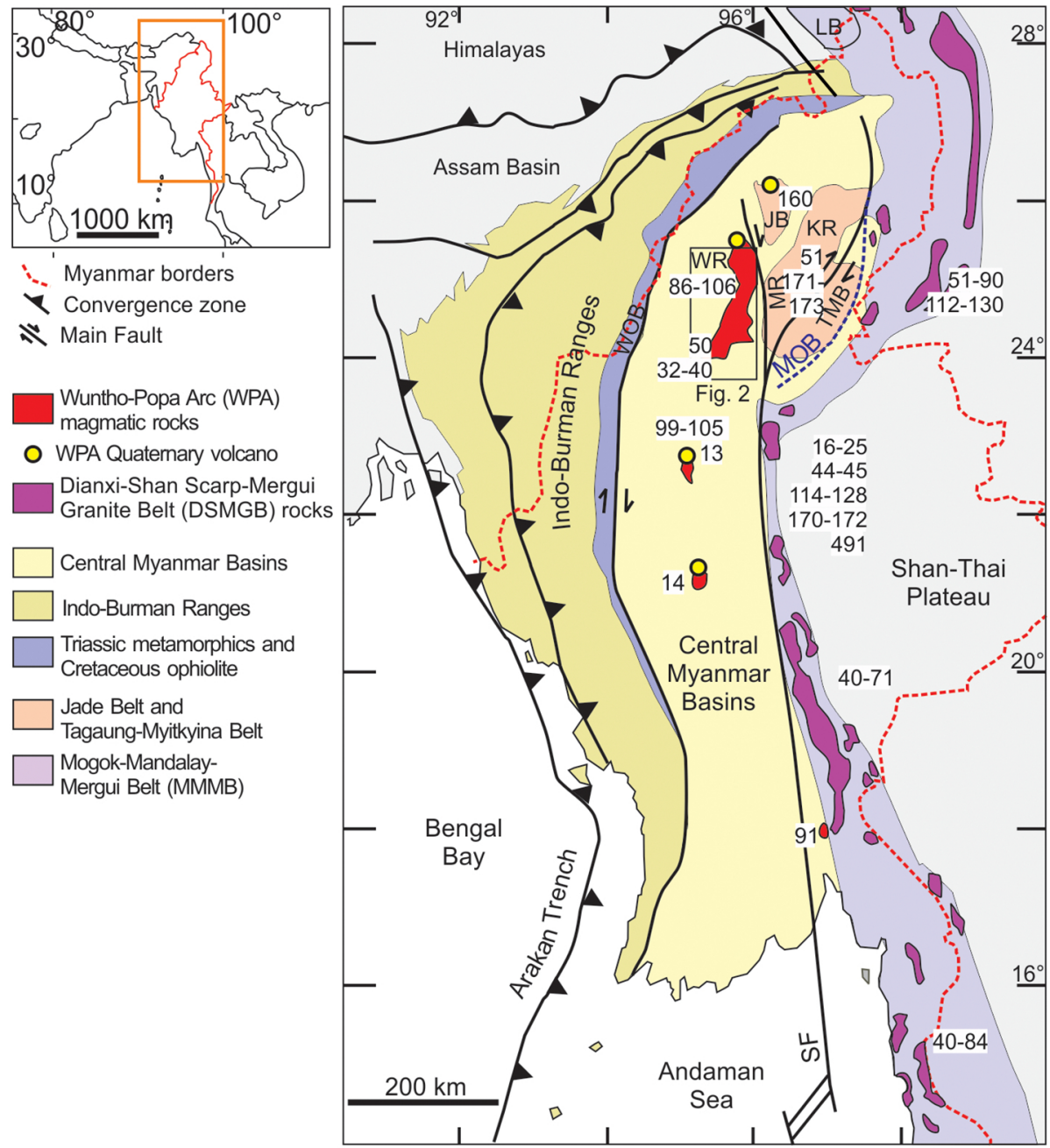

$\therefore$ Myanmar borders

Convergence zone

N Main Fault

Wuntho-Popa Arc (WPA)

magmatic rocks

O WPA Quatemary volcano

Dianxi-Shan Scarp-Mergui

Granite Belt (DSMGB) rocks

Central Myanmar Basins

Indo-Burman Ranges

Triassic metamorphics and Cretaceous ophiolite Jade Belt and

Tagaung-Myitkyina Belt Mogok-MandalayMergui Belt (MMMB)

Figure 2 
$\square$ Quaternary deposits

Oligo-Miocene Mu Group

Cenozoic Intrusives

$\begin{array}{lr}\text { Cenozoic Intrusives } & \\ \text { Upper K. - Lower-Oligo. } & 24^{\circ} \\ \text { Mansi Gale Group } & 40^{\prime} \mathrm{N}\end{array}$

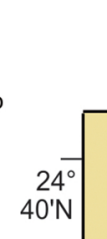

Cretaceous Kanza Chaung Batholith

$\square$ Granodiorite (I-type)

Diorite (I-type)

2-micas granite

Nankholon Formation

Albian- Cenommanian

Namakauk Limestone

Mawlin Formation

Maingthon Dacite

Jur.-mid K. (?)

Mawgyi Volcanics

$\square$ Triassic (?) metamorphics
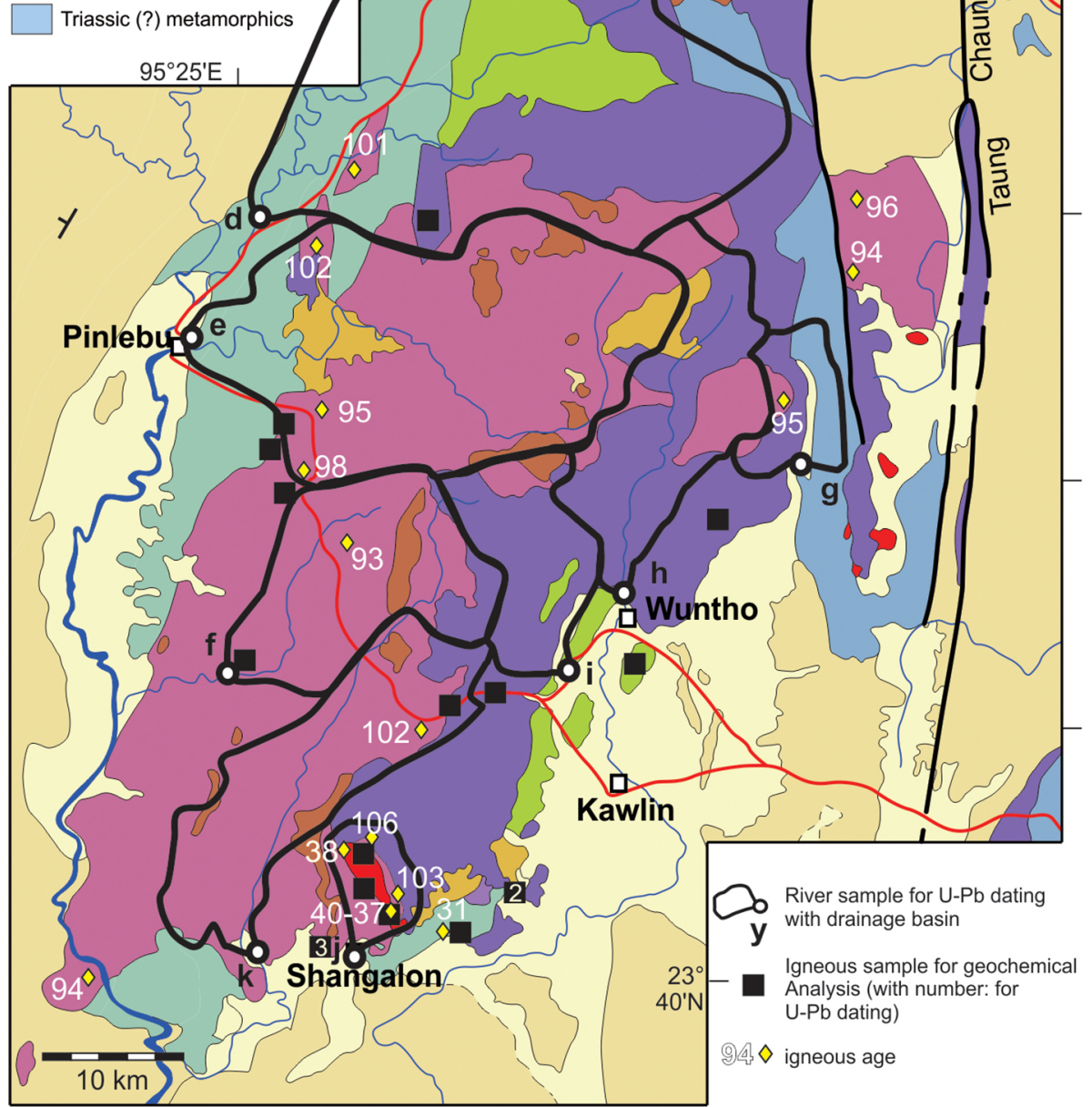


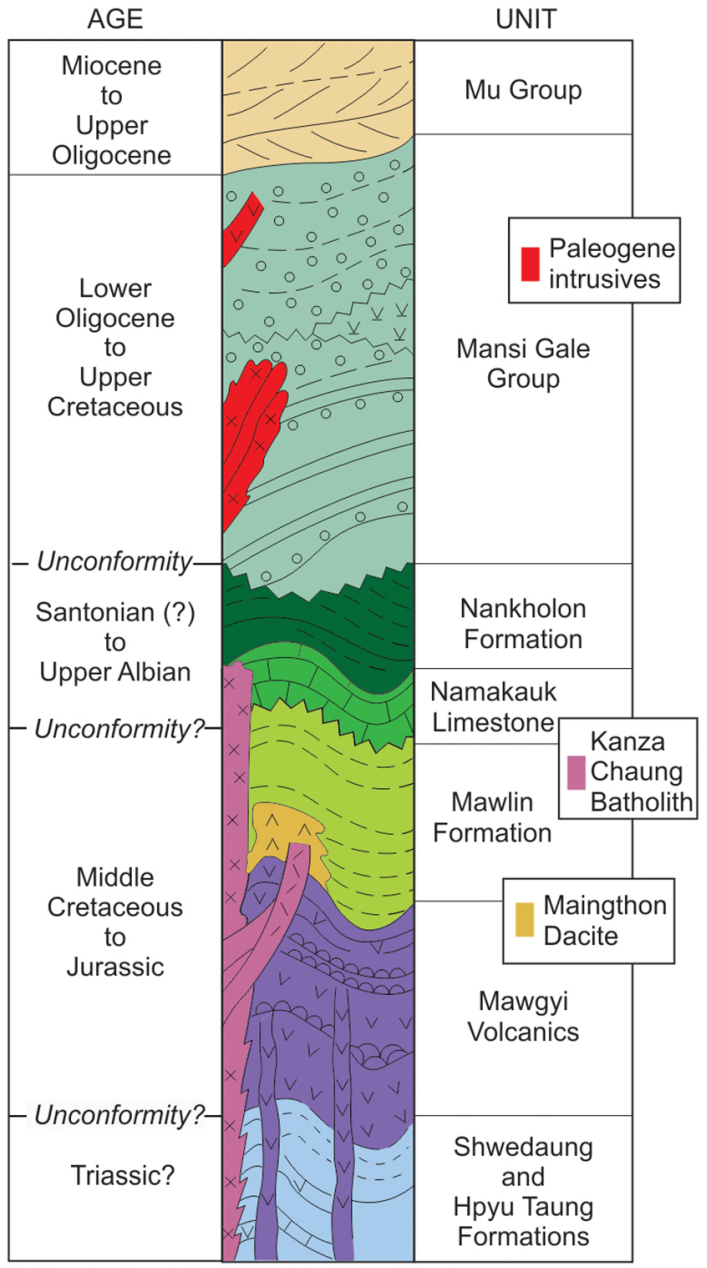




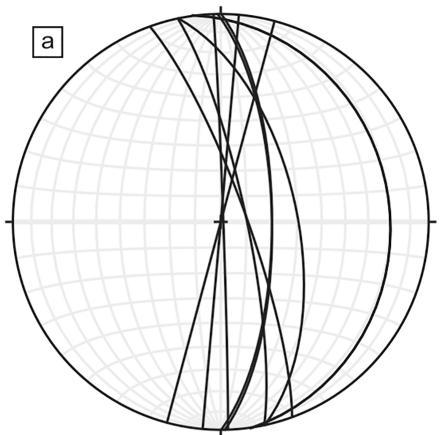

Shwedaung Formation bedding/foliiation $(n=10)$

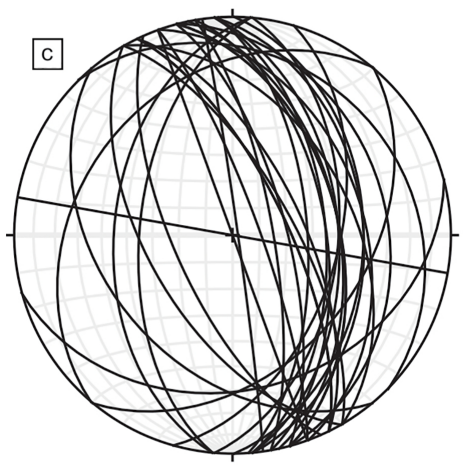

Maingthon Dacite layering/bedding $(n=33)$

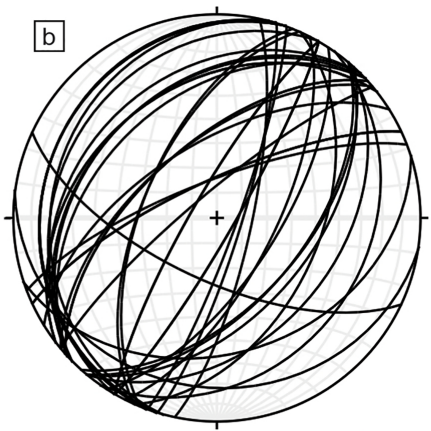

Mawgyi Volcanics, Mawlin Formation, Nankholon Formation, Namakauk Limestone, layering/bedding $(n=40)$

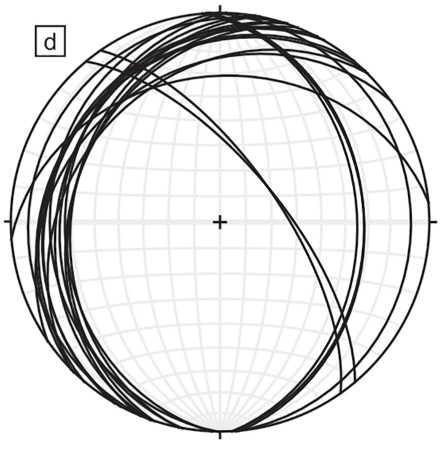

Upper Eocene - Oligocene Mansi Gale Group Layering/bedding (near Shangalon; $n=21$ )
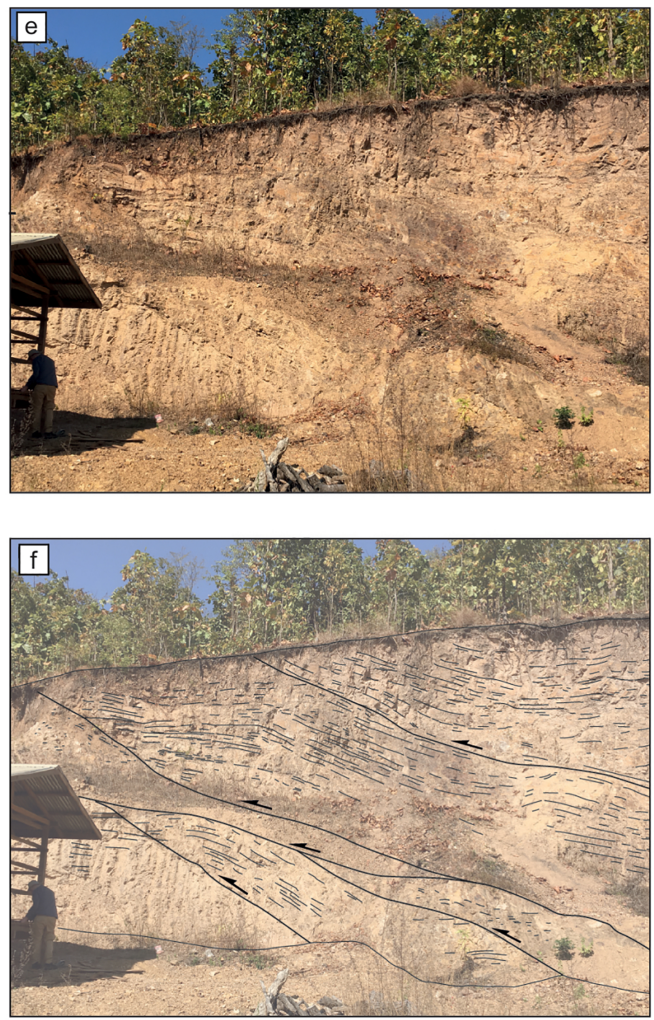

Figure 5 

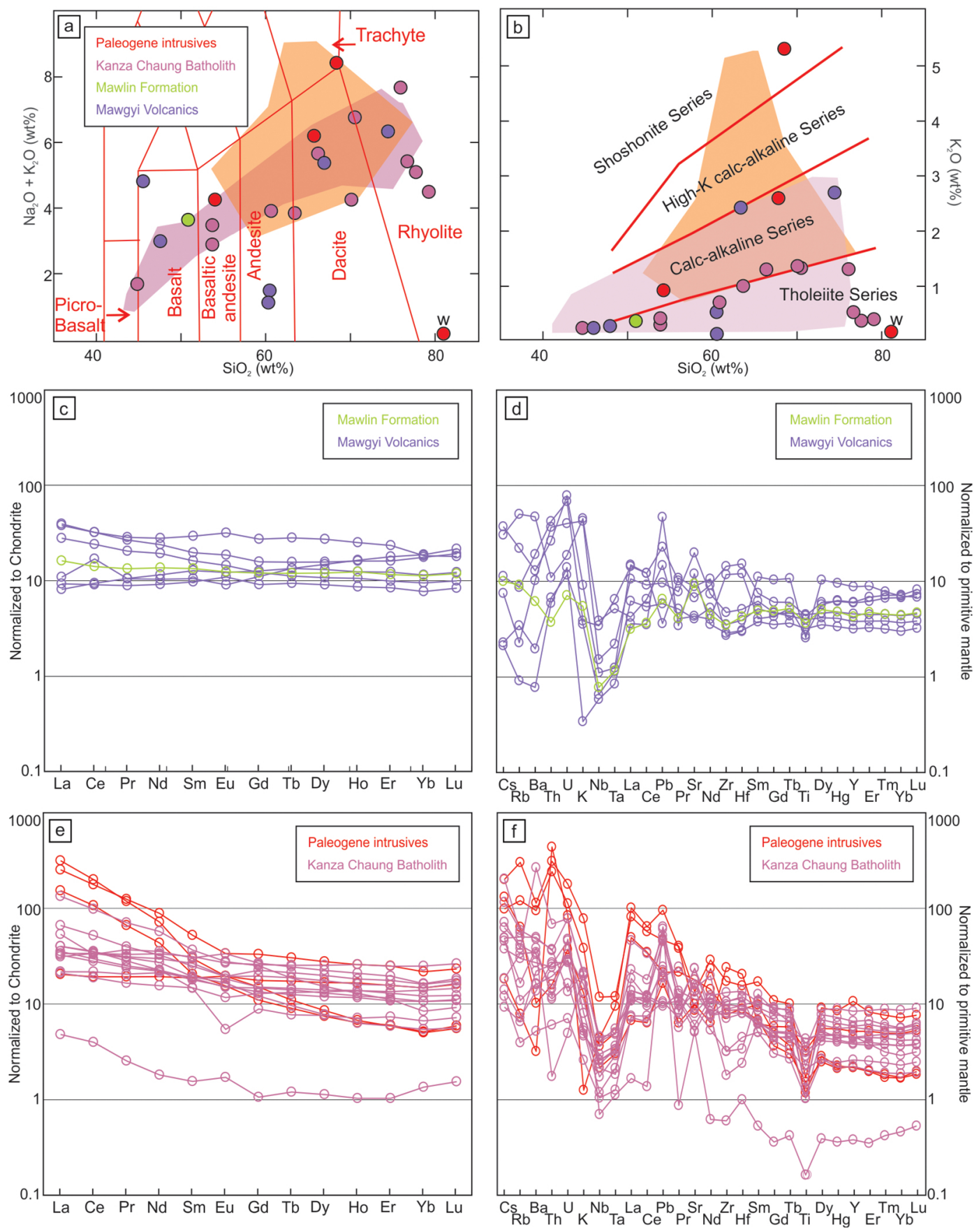

Figure 6 


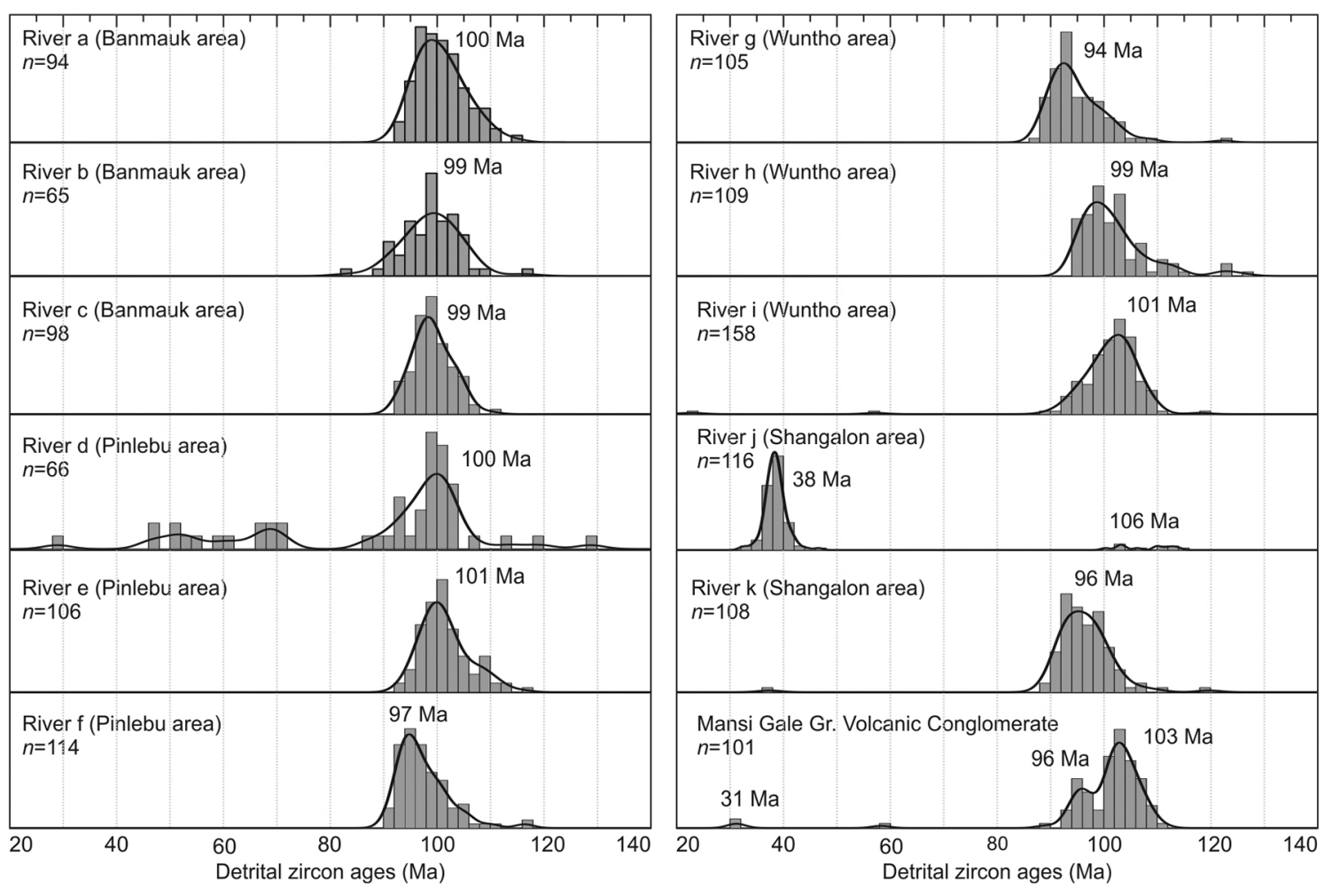

Figure 7 

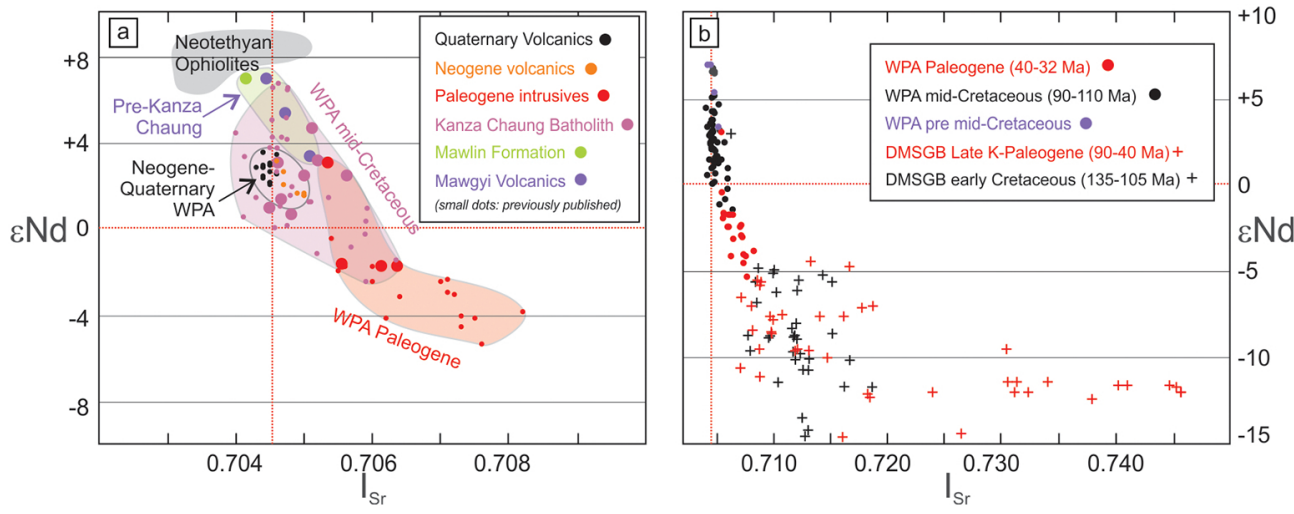

Figure 8 

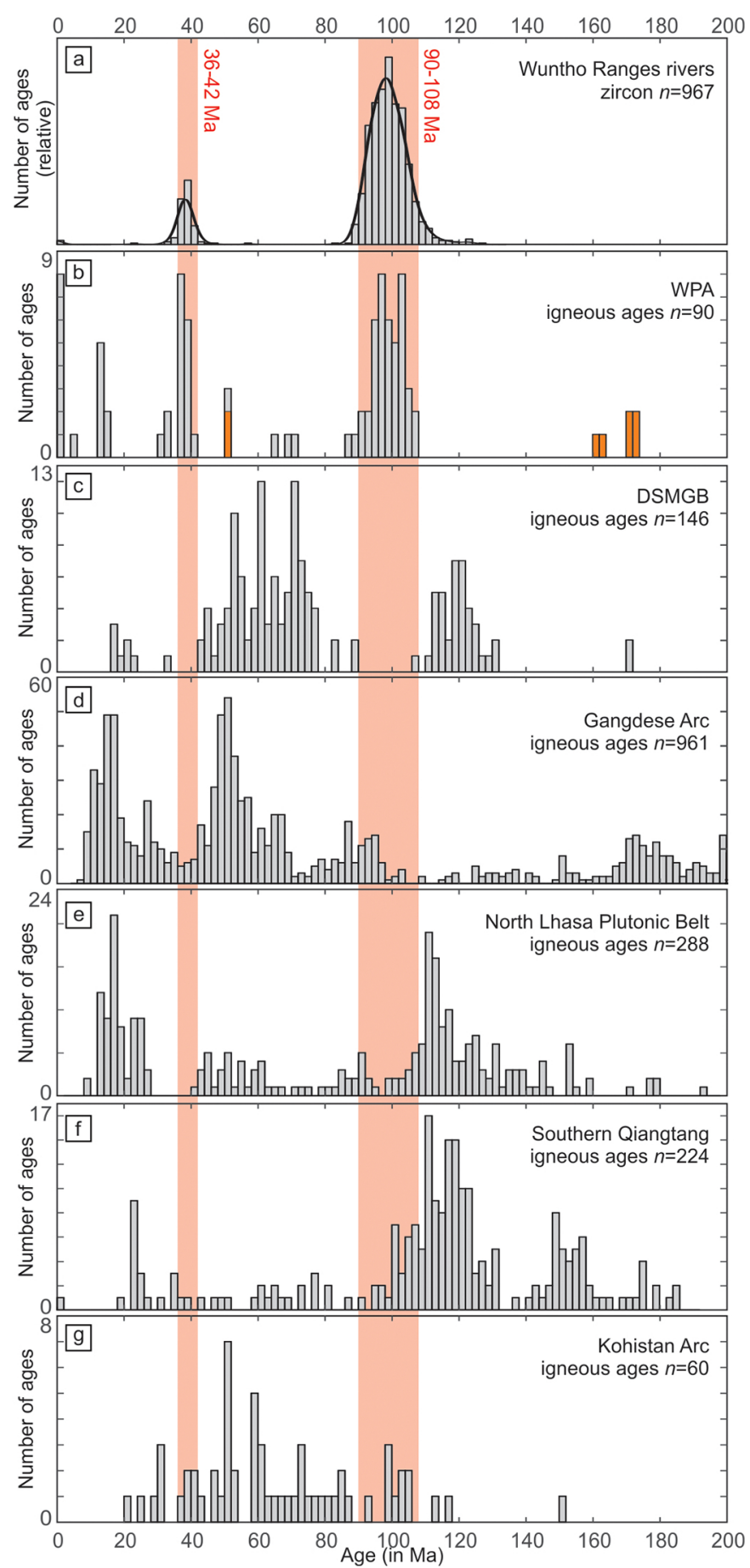

Figure 9 


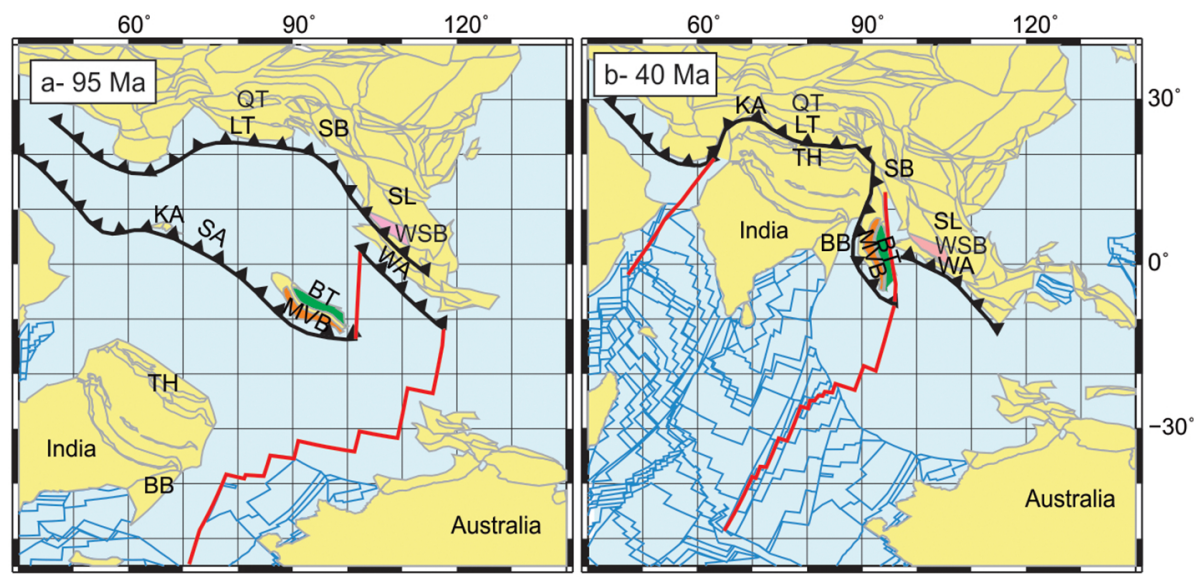

Figure 10 